\title{
Evidence linking calcium to increased organo-mineral association in soils
}

\author{
Mike C. Rowley (D) - Stephanie Grand (D) Jorge E. Spangenberg $(\mathbb{D} \cdot$ \\ Eric P. Verrecchia 1 )
}

Received: 27 October 2020/Accepted: 19 February 2021 / Published online: 4 April 2021

(C) The Author(s) 2021

\begin{abstract}
Geochemical indicators are emerging as important predictors of soil organic carbon (SOC) dynamics, but evidence concerning the role of calcium (Ca) is scarce. This study investigates the role of $\mathrm{Ca}$ prevalence in SOC accumulation by comparing otherwise similar sites with $\left(\mathrm{CaCO}_{3}\right.$-bearing) or without carbonates $\left(\mathrm{CaCO}_{3}\right.$-free). We measured the SOC content and indicators of organic matter quality (C stable isotope composition, expressed as $\delta^{13} \mathrm{C}$ values, and thermal stability) in bulk soil samples. We then used sequential sonication and density fractionation (DF) to separate two occluded pools from free and mineral-associated SOC. The SOC content, mass,
\end{abstract}

Responsible Editor: Justin B. Richardson.

Stephanie Grand and Eric P. Verrecchia co-supervised this work.

Supplementary Information The online version of this article (https://doi.org/10.1007/s10533-021-00779-7) contains supplementary material, which is available to authorized users.

M. C. Rowley $(\bowtie) \cdot$ S. Grand · J. E. Spangenberg ·

E. P. Verrecchia

Institut des dynamiques de la surface terrestre (IDYST),

Université de Lausanne, Lausanne, Switzerland

e-mail: mike.rowley@unil.ch

M. C. Rowley

Energy and Geosciences Division, Earth and

Environmental Sciences Area, Lawrence Berkeley

National Laboratory, Berkeley, CA, USA and $\delta^{13} \mathrm{C}$ values were determined in all the fractions. $\mathrm{X}$-ray photoelectron spectroscopy was used to investigate the surface chemistry of selected fractions. Our hypothesis was that occlusion would be more prevalent at the $\mathrm{CaCO}_{3}$-bearing site due to the influence of $\mathrm{Ca}$ on aggregation, inhibiting oxidative transformation, and preserving lower $\delta^{13} \mathrm{C}$ values. Bulk SOC content was twice as high in the $\mathrm{CaCO}_{3}$-bearing profiles, which also had lower bulk $\delta^{13} \mathrm{C}$ values, and more occluded SOC. Yet, contrary to our hypothesis, occlusion only accounted for a small proportion of total SOC $(<10 \%)$. Instead, it was the heavy fraction (HF), containing mineral-associated organic $\mathrm{C}$, which accounted for the majority of total SOC and for the lower bulk $\delta^{13} \mathrm{C}$ values. Overall, an increased $\mathrm{Ca}$ prevalence was associated with a near-doubling of mineral-associated SOC content. Future investigations should now aim to isolate Ca-mediated complexation processes that increase organo-mineral association and preserve organic matter with lower $\delta^{13} \mathrm{C}$ values.

Keywords Soil organic carbon - Density fractionation - Carbon stable isotopes $\cdot$ X-ray photoelectron spectroscopy $\cdot$ Rock-Eval ${ }^{\circledR}$ pyrolysis
Abbreviations
AGB
Above-ground biomass
BGB
Below-ground biomass 


\begin{tabular}{|c|c|}
\hline$\delta^{13} \mathrm{C}$ & $\begin{array}{l}\mathrm{C} \text { stable isotope ratio in per mil }(\%) \text { relative } \\
\text { to the Vienna Pee Dee Belemnite standard. }\end{array}$ \\
\hline DF & Density fractionation \\
\hline f-LF & Free-light fractions \\
\hline $\mathrm{HF}$ & $\begin{array}{l}\text { Heavy fractions/mineral-associated } \\
\text { fractions }\end{array}$ \\
\hline $\mathrm{LF}$ & Light fractions (f-LF, o-LF $\left.10,0-\mathrm{LF}_{200}\right)$ \\
\hline o- & Occluded light fractions separated at \\
\hline $\mathrm{LF}_{10}$ & $10 \mathrm{~J} \mathrm{~mL}^{-1}$ \\
\hline o- & Occluded light fractions separated at \\
\hline $\mathrm{LF}_{200}$ & $200 \mathrm{~J} \mathrm{~mL}^{-1}$ \\
\hline $\mathrm{OM}$ & Organic matter \\
\hline SE & Standard error of the mean \\
\hline SOC & Soil organic carbon \\
\hline SPT & Sodium polytungstate \\
\hline XPS & X-ray photoelectron spectroscopy \\
\hline
\end{tabular}

\section{Introduction}

Soil geochemical properties are emerging as important predictors of soil organic carbon (SOC) accumulation and content (Blankinship et al. 2018). Yet empirical data on the processes driving this relationship are still scarce. It is well established that iron $(\mathrm{Fe})$ and aluminium ( $\mathrm{Al}$ ) forms can stabilise SOC, leading to its accumulation in soils (Kögel-Knabner et al. 2008; Torn et al. 1997). Yet, calcium (Ca) forms can also play an important role in SOC accumulation (Boiteau et al. 2020; Martí-Roura et al. 2019; Oades 1988), mediating its stabilisation through several potential mechanisms (Rowley et al. 2018). Calcium is thought to indirectly contribute to the accumulation of occluded SOC through the promotion of aggregation (Muneer and Oades 1989b; Oades 1984, 1988) and to the accumulation of mineral-associated SOC through cation bridging processes (Edwards and Bremner 1967; Kalinichev and Kirkpatrick 2007; Sutton et al. 2005). However, very few studies have attempted to quantify the role of these separate processes in the accumulation of organic $\mathrm{C}$ in soils with a varied $\mathrm{Ca}$ content.

To investigate the processes that cause SOC to accumulate, bulk soil samples may be separated into physical pools through size or density fractionation (DF). Yet, due in part to methodological difficulties arising from the common presence of inorganic $\mathrm{C}$ in Ca-rich samples (Rovira et al. 1998), relatively few fractionation studies have focused on the role of $\mathrm{Ca}$ in SOC accumulation. Several studies have used DF on Ca-rich soils (Schrumpf et al. 2013; Vormstein et al. 2020; Wen et al. 2017), but fundamental uncertainties remain regarding the mechanisms that govern SOC accumulation in soils with a varied $\mathrm{Ca}$ prevalence (Rowley et al. 2018). These processes could be analysed by evaluating how SOC pools vary in otherwise similar soils with either a large or limited prevalence of $\mathrm{Ca}$.

Differences in SOC dynamics can lead to changes in the properties or quality of organic matter (OM) within a soil profile. In particular, the $\mathrm{C}$ stable isotope composition ( $\delta^{13} \mathrm{C}$ values) of $\mathrm{OM}$ can be used to investigate the transformation of SOC in different pools or fractions. The $\delta^{13} \mathrm{C}$ values of SOC typically increase by approximately 1-3\%o with depth, which has been linked to fractionation during oxidative microbial transformation processes (Boström et al. 2007; Hasinger et al. 2015; Hobbie et al. 1999). Variations in $\delta^{13} \mathrm{C}$ values between different soils have also been reported, which could not be ascribed to differences in vegetation, and thus, are most likely explained by differences in OM transformation processes. Minick et al. (2017) demonstrated that bulk $\delta^{13} \mathrm{C}$ values were lower in soils after Ca-addition $\left(\mathrm{CaSiO}_{3}\right)$, relative to control soils with a limited $\mathrm{Ca}$ prevalence. Increased aggregation, driven by the flocculation of soil separates by $\mathrm{Ca}^{2+}$ (Muneer and Oades 1989b), could occlude and physically protect SOC from oxidative microbial transformation processes; thereby inhibiting fractionation and preserving low $\delta^{13} \mathrm{C}$ values (Minick et al. 2017). However, this hypothesis still requires empirical confirmation.

The thermal stability of OM has also been proposed as a proxy for SOC dynamics (Plante et al. 2009; Sanderman and Grandy 2020). Among thermal analysis techniques, Rock-Eval ${ }^{\circledR}$ analysis can provide insights into OM quality changes (Disnar et al. 2003; Matteodo et al. 2018; Poeplau et al. 2017). In particular, the $I$ and $R$ Index scores, calculated from the amounts of hydrocarbon compounds released during pyrolysis, have been proposed as an indicator of variations in the OM quality of diverse soils (Sebag et al. 2006; Sebag et al. 2016). In a study covering a range of geochemically diverse soil types across the Swiss Alps, Matteodo et al. (2018) discovered that $\mathrm{CaCO}_{3}$-bearing profiles typically had lower $R$ Index scores (lower thermal stability). Yet, more 
investigation into the effects of $\mathrm{Ca}$ prevalence on the thermostability of SOC are still needed as a recent study conversely demonstrated that Ca-addition increased the thermal stability of model $\mathrm{C}$ substrates (Barreto et al. 2020). These measures of OM quality could also be coupled with surface-sensitive analyses such as X-ray photoelectron spectroscopy (XPS), to yield complementary information on the oxidative transformation of SOC and its interactions with other elements. Yet, to our knowledge these complementary techniques have not been combined to investigate the effects of a varied $\mathrm{Ca}$ prevalence on $\mathrm{OM}$ quality in different SOC pools.

To investigate the influence of $\mathrm{Ca}$ prevalence on SOC accumulation mechanisms, three profiles from a $\mathrm{CaCO}_{3}$-bearing and $\mathrm{CaCO}_{3}$-free site, which had developed under similar soil forming conditions (Rowley et al. 2020), were fractioned by sequential sonication and density separation. Samples were split into four fractions (a free-light fraction, two occludedlight fractions, and a heavy fraction) to investigate whether SOC was predominantly stored within free particulate OM, aggregates of increasing sonication resistance (assumed to represent aggregates of differing tensile strength), or mineral-association, respectively. We measured the SOC content, $\delta^{13} \mathrm{C}$ values, and Rock-Eval ${ }^{\circledR}$ thermal signature of bulk (unfractionated) soil samples. We also quantified the SOC content, mass, and $\delta^{13} \mathrm{C}$ values in all the fractions. Finally, we measured a subset of fractions with XPS to characterise the surface chemistry of our samples. Our guiding hypothesis was that the flocculation of soil separates by $\mathrm{Ca}^{2+}$ would cause an accumulation of occluded SOC at the $\mathrm{CaCO}_{3}$-bearing site. Furthermore, we hypothesised that this occlusion would inhibit microbially-driven oxidative transformation of SOC and its associated $\mathrm{C}$ isotope fractionation, resulting in lower bulk $\delta^{13} \mathrm{C}$ values. Overall, we found that occlusion played a minimal role in SOC dynamics at either site (accounting for $<10 \%$ of total organic C). It was instead the mineral-associated fraction that explained the two-fold difference in SOC content and the divergence in bulk $\delta^{13} \mathrm{C}$ values.

\section{Materials and methods}

Site description and sampling

This study was completed in the Nant Valley (573'000, 119'000, CH1903 LV03), Vaud Alps, Switzerland. The Valley is situated on the Morcles Nappe, which is a tectonic unit consisting of Jurassic and Cretaceous shallow-water limestones intercalated with marl and shale deposits (Austin et al. 2008). Sampling took place in the rangeland (Suppl. Fig. S1) described in detail by several studies (Ceperley et al. 2020; Grand et al. 2016; Rowley et al. 2020; Vittoz and Gmür 2008). The rangeland is $1500 \mathrm{~m}$ above sea level, receives approximately $1800 \mathrm{~mm}$ year $^{-1}$ precipitation, and has a mean annual temperature of $6^{\circ} \mathrm{C}$ (Vittoz and Gmür 2008).

Two sampling sites were selected at the rangeland. We dug three profiles at each site (Suppl. Fig. S1), which were characterised (IUSS Working Group WRB 2015) as being either Eutric Cambisols (siltic) with no $\mathrm{CaCO}_{3}\left(\mathrm{CaCO}_{3}\right.$-free; F1, F2, F3) or Cambic Phaeozems (siltic) with a small $(<6.2 \%) \mathrm{CaCO}_{3}$ content $\left(\mathrm{CaCO}_{3}\right.$-bearing; B1, B2, B3). Profiles were sampled at 6-7 depth intervals and labelled from 1 to 6/7 with increasing depth (e.g., F1.1-to-F1.6). The texture, silicate mineralogy, and elemental composition of the profiles were highly similar except for an increased relative abundance of $\mathrm{Ca}$ in the Cambic Phaeozems (see Rowley et al. 2020 for details). Both above- and below-ground biomass (AGB and BGB) were also randomly sampled at both sites to assess potential variations in the $\delta^{13} \mathrm{C}$ values of vegetation.

Sample preparation

Samples of AGB and BGB were oven-dried $\left(65^{\circ} \mathrm{C}\right.$, to constant weight) and ground by hand. Air-dried soil samples were sieved to $2 \mathrm{~mm}$ prior to density fractionation. A subsample of each bulk soil sample was ground in a rotary mill for SOC elemental and isotope analyses (Rowley et al. 2020). Prior to these analyses, inorganic $\mathrm{C}$ was removed through a $\mathrm{HCl}$ fumigation procedure and a correction factor was applied to account for changes in mass (Harris et al. 2001). 
Laboratory analysis

Quality control procedures included the analysis of an internal standard when appropriate, as well as the inclusion of blanks and quality checks.

\section{Density fractionation}

Soil samples were fractioned into four SOC pools (Fig. 1a, d) using sequential sonication and density separation (Golchin et al. 1994; Poeplau et al. 2018; Viret and Grand 2019). A $7 \mathrm{~g}$ soil aliquot was combined with $35 \mathrm{~mL} 1.6 \mathrm{~g} \mathrm{~cm}^{-3}$ sodium polytungstate (SPT) in $50 \mathrm{~mL}$ centrifuge tubes and inverted 10 times by hand to liberate the f-LF. Samples were then left to settle for $30 \mathrm{~min}$ before centrifuging (1080 $\mathrm{g}$ for $30 \mathrm{~min})$ to separate the floating free-light fractions (f-LF) from the remaining sample. The floating f-LF were decanted onto $0.45 \mu \mathrm{m}$ nitrocellulose membranes and vacuum filtered. The f-LF remaining on the filter were then thoroughly rinsed thoroughly with deionised water (Schrumpf et al. 2013) and washed into aluminium drying boats (Fig. 1a).

Sodium polytungstate was placed back into the tubes and the samples were then sequentially sonicated using a pre-calibrated QSonica Q500 Sonicator with a model cl-334 Sonication Node (see North 1976 and Schmidt et al. 1999 for details on the methods). Sonication energies were selected after pretesting, which revealed that higher sonication energies (up to $590 \mathrm{~J} \mathrm{~mL}^{-1}$; Schmidt et al. 1999; Kaiser and Berhe 2014) did not increase the recovery of occluded material at either site (data not shown; Golchin et al. 1994; Schrumpf et al. 2013). The output energy of the Sonication Node was calibrated calorimetrically according to Schmidt et al. (1999). Tubes were placed in an ice slurry to dissipate heat transferred from the sonicator node, which was run at $20 \%$ amplitude. The first sonication was carried out at $10 \mathrm{~J} \mathrm{~mL}^{-1}$, separating the first set of occluded fractions $\left(\mathrm{o}-\mathrm{LF}_{10}\right)$ in the same manner as the f-LF (Fig. 1b). The samples were then recombined with the SPT and sonicated a second time to $200 \mathrm{~J} \mathrm{~mL}^{-1}$, prior to separating the floating material in the same manner as the f-LF and $\mathrm{o}-\mathrm{LF}_{10}$, resulting in the recovery of a second set of occluded fractions (o- $\mathrm{LF}_{200} ;$ Fig. 1c). The remaining heavy fractions (HF; Fig. 1d) were rinsed five times by centrifugation $(30 \mathrm{~min}$ at $7500 \times g$ ) until conductivity

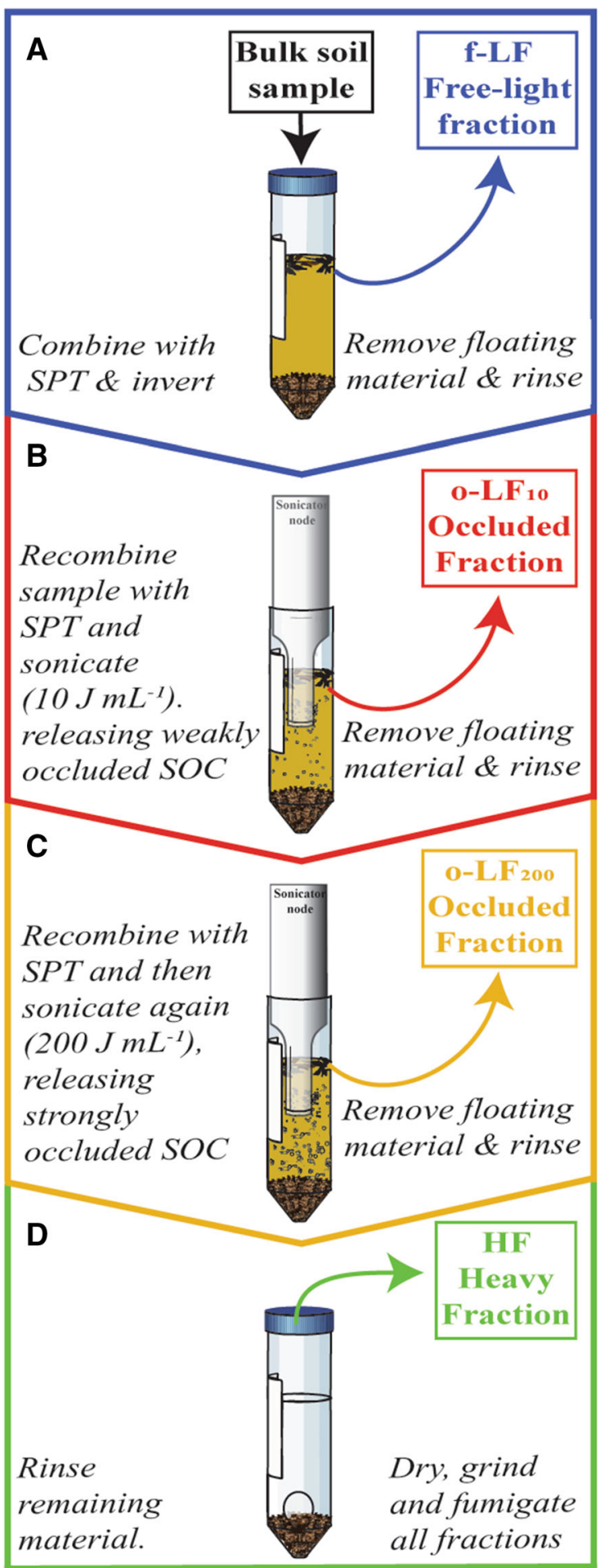

was reduced to $<100 \mu \mathrm{S}$ (Schrumpf et al. 2013). To ensure effective removal of the SPT, HF centrifuge pellets were disrupted with a $1 \mathrm{~mm}$ glass bead on a 
४Fig. 1 Schematic showing the sequential sonication and density separation process. a The free-light fraction (f-LF) was first fractionated from the bulk soil by inverting the sample. b The first occluded light fraction $\left(\mathrm{o}-\mathrm{LF}_{10}\right)$ was then separated after $10 \mathrm{~J} \mathrm{~mL}^{-1}$ sonication. $\mathbf{c}$ The second occluded light fraction (o$\mathrm{LF}_{200}$ ) was then separated after $200 \mathrm{~J} \mathrm{~mL}^{-1}$ sonication. $\mathbf{d}$ The remaining mineral-associated material then forms the heavy fraction (HF). All fractions were thoroughly rinsed prior to analysis.

vortex (Fig. 1d) and then placed on a rotary shaker (10 min at $250 \mathrm{rpm}$ ) between rinses (Schrumpf et al. 2013). Once rinsed, all fractions were oven dried at $65{ }^{\circ} \mathrm{C}$ and weighed to the nearest $\mathrm{mg}$. Subsamples of the HF were ground in a ball mill, while the LFs were ground to a fine powder by hand. To ensure accurate and replicable fractionation, DF was run in triplicate for each soil sample. Recovery rates ranged from 98 to $100 \%$ (Suppl. Table S1). There was no o-LF 10 recovered from sample F1.6.

The precipitation of Ca-metatungstate on light fraction material in soils with a high $\mathrm{Ca}$ prevalence could create a false equivalence between the light fractions (LFs; free and occluded fractions combined) and HF (Rovira et al. 1998). This has been observed in soils with higher quantities of $\mathrm{CaCO}_{3}(>40 \%$; Rovira et al. 1998) than our $\mathrm{CaCO}_{3}$-bearing site $(<6.2 \%)$. Significant precipitation of Ca-metatungstate on our fractions can however be ruled-out because: (i) recovery during DF was not higher at the $\mathrm{CaCO}_{3}$-bearing site (Suppl. Table S1), (ii) XPS (methods detailed below) revealed that $\mathrm{W}$ contamination was lowest in the HF, with no difference between the sites (Suppl. Table S2), and (iii) there was also no peak detected for Ca-metatungstate (shift towards $35 \mathrm{eV}$ ) in the detailed scans of the $\mathrm{W}_{4 \mathrm{f}}$ region (Suppl. Fig. S2). Thus, these differences did not seem to arise due to the precipitation of Ca-metatungstate on fresh particulate OM, but future studies should be aware of the risks of running DF on $\mathrm{CaCO}_{3}$-bearing soil samples ( $>20 \%$ ).

Soil organic carbon analysis $\left(\delta^{13} C\right.$ values and RockEval $($ )

Soil organic carbon content and C isotope compositions of bulk samples, triplicates of density fractions, AGB, and BGB were determined using a Carlo Erba 1108 elemental analyser connected to a Thermo Fisher Delta V isotope-ratio mass spectrometer (EA/IRMS system from Bremen, Germany). The EA/IRMS was operated in continuous He flow mode via a split interface (Conflo II). Combustion of samples occurred within pre-weighted $\mathrm{Sn}$ capsules in an $\mathrm{O}_{2}$ atmosphere at $1020^{\circ} \mathrm{C}$. The carbon isotope compositions were expressed in the delta $(\delta)$ notation as the per mil (\%o) difference of the ${ }^{13} \mathrm{C} /{ }^{12} \mathrm{C}$ ratio in the sample relative to the Vienna Pee Dee Belemnite standard $\left(\delta^{13} \mathrm{C}\right.$ in \%o VPDB; Coplen 2011). A 3-point calibration with international reference materials and in-house standards was used to calibrate and normalise the isotopic ratios to the international scale (VPDB-LSPVEC lithium carbonate). The intermediate precision and accuracy of the EA/IRMS analyses was assessed through replicate analyses of separate reference materials and was better than $0.05 \%$. $\mathrm{N}$ measurements were not established in this study with the EA/ IRMS, but bulk values, established on a different elemental analyser can be found in Rowley et al. (2020). Percentages are presented on a mass basis. The mass of SOC in the different fractions was calculated by multiplying the SOC content by the quantity of material recovered in each fraction.

The thermal stability of OM in ground and nonfumigated bulk-soil samples was also measured with a Rock-Eval ${ }^{\circledR} 6$ Pyrolyser (Vinci Technologies, RueilMalmaison, France). Full details on the Rock-Eval ${ }^{\circledR}$ methods and different indices can be found in the supplementary information, "Materials and methods". The S2 thermogram was split into 5 separate components (A1:A5) at fixed temperature bounds and then used to calculate the $I$ and $R$ Index scores according to Eqs. 1 and 2 (Malou et al. 2020; Sebag et al. 2016). The $I$ and $R$ Index scores from our samples were then compared to the negative linear trend ("humic" trend) from geochemically- (Matteodo et al. 2018) and pedoclimatically-diverse datasets (Sebag et al. 2016). This trend in thermal stability is commonly ascribed to changes in OM quality upon decomposition in soils (Malou et al. 2020; Thoumazeau et al. 2020).

$$
\begin{aligned}
& I=\log _{10}\left(\frac{(\mathrm{A} 1+\mathrm{A} 2)}{\mathrm{A} 3}\right) \\
& R=\frac{\mathrm{A} 3+\mathrm{A} 4+\mathrm{A} 5}{100}
\end{aligned}
$$




\section{$X$-ray photoelectron spectroscopy}

All the fractions of a surface and subsoil sample from a randomly selected profile at each site were measured (B2.1 to B2.4; F2.1 to F2.4) using a PHI VersaProbe II Scanning XPS Microprobe (Physical Instruments AG, Feldkirchen, Germany). Measurements with the XPS were performed at the Surface Characterization Laboratory, Ecole Polytechnique Fédérale de Lausanne. Sample topography can influence XPS measurements due to differences in photoelectron emission geometry (Zemek et al. 2008). Thus, powdered fractions were loaded onto stubs in a homogeneous manner. The surface of samples ( $<10 \mathrm{~nm}$ depth; Yuan et al. 1998) was then analysed with a monochromatic $\mathrm{Al} \mathrm{K} \alpha \mathrm{X}$-ray source $(1486.6 \mathrm{eV})$ with a beam size of $200 \mu \mathrm{m}$ at $45.7 \mathrm{~W}$. The spherical capacitor was set at $45^{\circ}$ take-off angle respective to the surface of samples. Samples were scanned twice, once coarsely (regional scans), with a pass energy of $187.9 \mathrm{eV}$, which yielded the principal elements of interest. The samples were then scanned again in more detail (survey scans) using a pass energy of $47 \mathrm{eV}$ to investigate the identified surficial elements. Exposure time was $<30 \mathrm{~min}$ to prevent X-ray induced alteration of the density fractions and subsequent false $\mathrm{C}$ assignments (Dengis et al. 1995). Vacuum inside the main chamber was in low 10 torr during measurements $(-7 \mathrm{~Pa})$. Sample charging during analysis caused peak shifts of $<3 \mathrm{eV}$, which were corrected based on the maximum principal $\mathrm{C}_{1 \mathrm{~s}}$ peak, centred at $285 \mathrm{eV}$ (Mikutta et al. 2009).

Atomic quantification of the surface of samples was completed using a process of background linear subtraction, fitting a set of Gaussian curves to spectra and converting intensities into atomic abundancies with sensitivity factors (Moulder and Chastain 1992). Curve fitting of survey scans was performed using PHI Multipak $9.5^{\mathrm{TM}}$ Software. Identification of binding energies was completed according to Moulder and Chastain (1992). Spectral shifts in core level $C_{1 s}$ binding energies were assigned according to Table 1 , deconvoluting the $C_{1 s}$ peak into sub-peaks that are indicative of different $\mathrm{C}$ bonding environments (Suppl. Fig. S4; Jones and Singh 2014). Sub-peaks were fitted with Gaussian-Lorentzian functions, the full-width-at-half-maximum was allowed to vary between 1 and 2. The ratio of aliphatic/ aromatic C to oxidised $\mathrm{C}$ moieties (alcoholic/phenolic, carbonyl, carboxylate groups) was used to quantify the degree of oxidative transformation of surficial C (Yeasmin et al. 2017).

\section{Statistical analysis}

The effects of the presence or absence of $\mathrm{CaCO}_{3}$ on SOC distribution and $\delta^{13} \mathrm{C}$ values were investigated using linear mixed models. Models were fitted using SAS $9.4^{\mathrm{TM}}$. The estimation method was set to restricted (residual) maximum likelihood. Residuals were checked for goodness of fit and normality with quantile-quantile plots (Galecki and Burzykowski 2015). Deviations from homoscedasticity were evaluated by plotting conditional residuals against predicted values. The significance of fixed effects was evaluated using type III F-tests. The Satterthwaite adjustment was used to compute the degrees of freedom of the denominators (Satterthwaite 1946). Comparison of the means of significant variables were completed using t-tests without multiple inference adjustment (Webster 2007). The alpha level $(\alpha)$ of significance was set at 0.05 . All reported means in "Results" are conditional least-square means \pm standard error of the mean.

Separate models were constructed for the analysis of bulk soil and DF measurements. Simpler model structures were used for bulk observations because

Table 1 Binding energies of specific carbon $\mathrm{C}_{1 \mathrm{~s}}$ sub-peaks and their associated $\mathrm{C}$ bonding environment

\begin{tabular}{lll}
\hline Associated carbon bond environment & Bond type & Fixed binding energy (eV) \\
\hline Aliphatic/aromatic & $\mathrm{C}-\mathrm{H} / \mathrm{C}-\mathrm{C}$ & 285 \\
Alcoholic/phenolic & $\mathrm{C}-\mathrm{OH}$ & 286.5 \\
Carbonyl & $\mathrm{C}=\mathrm{O}$ & 288 \\
Carboxylate & $\mathrm{O}=\mathrm{C}-\mathrm{OH}$ & 289.5 \\
\hline
\end{tabular}

The figures below have been adapted from Jones and Singh (2014) and Moulder and Chastain (1992) 
they were based upon singular rather than triplicate measurements. Full details on the model structures used for bulk observations can be found in the supplementary information, "Materials and methods". Models that were used to analyse DF triplicate observations included site $\left(\mathrm{CaCO}_{3}\right.$-free or $\mathrm{CaCO}_{3}$ bearing), classes of sample depth $(0-5 \mathrm{~cm}, 5-10 \mathrm{~cm}$, etc....), fractions (f-LF, o-LF $10,0-\mathrm{LF}_{200}$, and HF), and their interactions as fixed effects. Depth was set as a random effect with a first-order autoregressive covariance structure, while variance estimates were permitted to vary between sites. Rather than using the mean of triplicate observations as the response variable, each observation was accounted for separately. This was achieved by setting each fraction as a repeated measure with a variance component covariance structure. Variance estimates were also allowed to vary between the LFs or the HF to account for data heteroscedasticity.

\section{Results}

Bulk soil

The SOC content in bulk samples (unfractionated) was twice as high at the $\mathrm{CaCO}_{3}$-bearing site (Suppl. Table S3). Bulk $\delta^{13} \mathrm{C}$ values increased systematically with depth at both sites. As hypothesised, bulk $\delta^{13} \mathrm{C}$ values were lower at the $\mathrm{CaCO}_{3}$-bearing site relative to the $\mathrm{CaCO}_{3}$-free site, with an average offset of approximately $0.8 \%$. The $\delta^{13} \mathrm{C}$ values of $\mathrm{AGB}$ were lower at the $\mathrm{CaCO}_{3}$-free site, but $\mathrm{BGB} \delta^{13} \mathrm{C}$ values were indistinguishable between the sites (Fig. 2).

The Rock-Eval ${ }^{\circledR}$ results for bulk samples were well within the bounds of usual $I$ and $R$ Index scores, falling just below the typical decomposition trend (Fig. 3; "humic" trend of Sebag et al. 2016). In the B horizons, the $\mathrm{CaCO}_{3}$-free profiles had slightly higher I Index scores (Suppl. Table S3). The $\mathrm{CaCO}_{3}$-free samples also had a higher proportion of A5 contribution to the S2 thermogram (pyrolysis curve; Suppl. Fig. S5), ensuring that their $R$ Index scores remained approximately equivalent to that of the $\mathrm{CaCO}_{3}$-bearing samples. Thus, $\mathrm{B}$ horizons of $\mathrm{CaCO}_{3}$-free profiles had an S2 thermogram that was more-distributed compared to their $\mathrm{CaCO}_{3}$-bearing counterparts, with both high (A5) and low-temperature (A1) pyrolysis products being relatively abundant.

\section{Density fractions}

\section{Distribution of material and SOC between fractions}

The proportion of sample mass in a fraction refers to the amount of material recovered in a specific fraction, relative to the original bulk sample mass. At both sites, the largest proportion of sample mass was recovered in

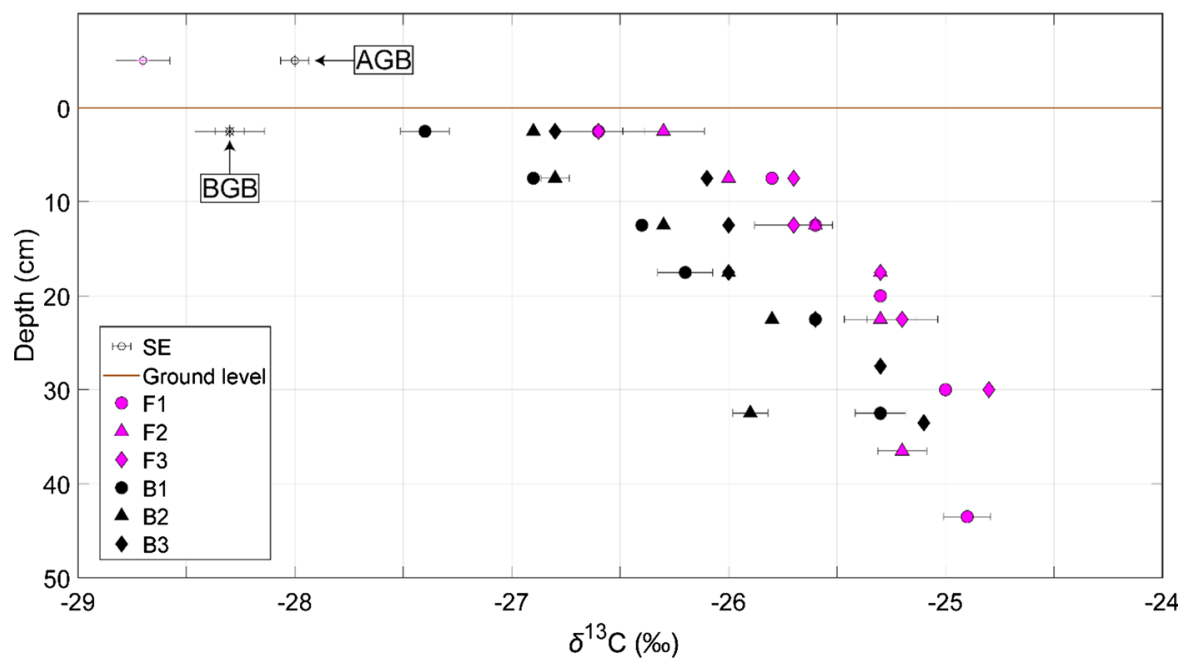

Fig. 2 Carbon isotope compositions $\left(\delta^{13} \mathrm{C}\right.$ values, \%o vs. VPDB) of bulk soil organic carbon, above-ground (AGB) and below-ground biomass (BGB) from the $\mathrm{CaCO}_{3}$-free $(\mathrm{F}$ in fuchsia) and $\mathrm{CaCO}_{3}$-bearing ( $\mathrm{B}$ in black) site. Error bars represent the standard error of the mean (SE) of duplicate measurements 


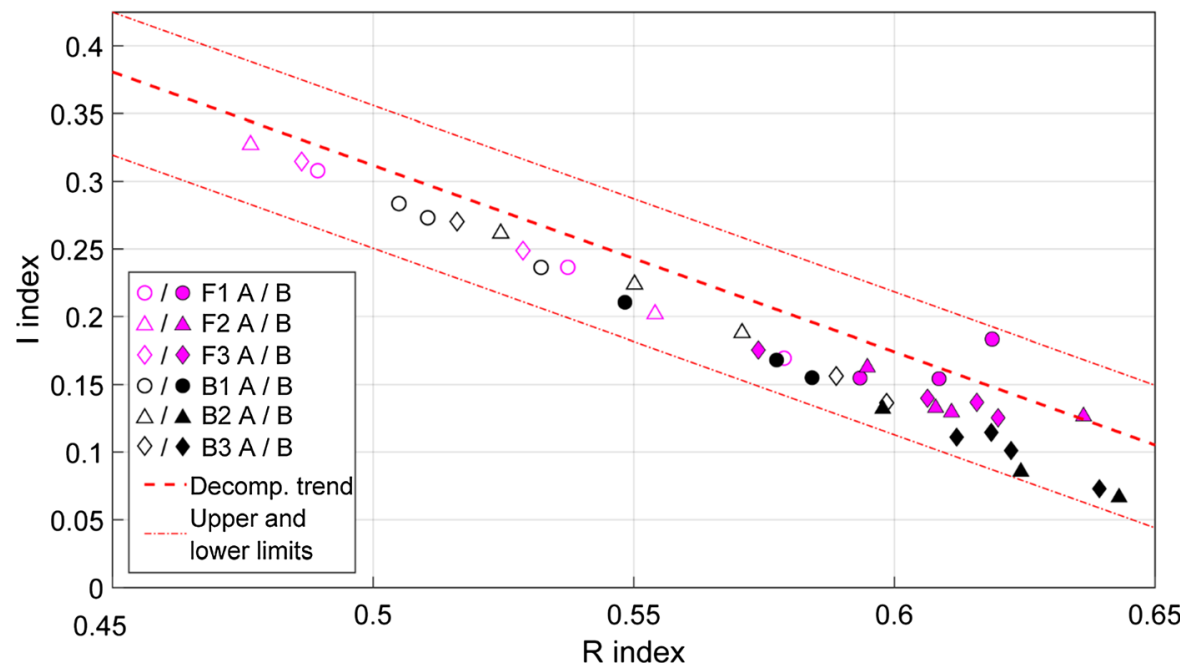

Fig. 3 Rock-Eval ${ }^{\circledR} I$ and $R$ Index scores of bulk soil from the $\mathrm{CaCO}_{3}$-free (in fuchsia) and $\mathrm{CaCO}_{3}$-bearing (in black) profiles, split by horizon (A horizon with hollow symbol/B horizon with filled symbol). Both the linear decomposition (Decomp.) trend ("humic" trend) and upper/lower boundaries of the range of

the HF (Suppl. Table S1) and the smallest proportion of sample mass was recovered in the o- $\mathrm{LF}_{10}$ (Suppl. Fig. S7a, d). The proportion of sample mass recovered in the occluded light fractions was higher at the $\mathrm{CaCO}_{3}$-bearing site.

SOC content refers to the concentration of organic carbon within a sample, where percentages are reported on a mass basis. The SOC content of the HF were similar to the bulk soil at both sites, differing most in surficial horizons (Suppl. Fig. S8): which had a larger proportion of sample mass recovered in the LFs, relative to deeper samples. Consistently with bulk soil results, the SOC content of the HF were higher at the $\mathrm{CaCO}_{3}$-bearing site.

The mass of SOC in the different fractions was calculated by multiplying the quantity of material recovered in each fraction by its SOC content. The mass of SOC in the LFs were always at least an order of magnitude lower than the HF at both sites (Fig. 4a, b). The mass of SOC in the LFs were always higher at the $\mathrm{CaCO}_{3}$-bearing site than the $\mathrm{CaCO}_{3}$-free site (Fig. 4c, d; f-LF $=1.3 \pm 0.1$ vs. $0.6 \pm 0.1 \mathrm{mg}$ $\mathrm{C} \mathrm{g}^{-1} ; \quad$ o- $-\mathrm{LF}_{10}=0.7 \pm 0.1$ vs. $0.1 \pm 0.1 \mathrm{mg} \mathrm{C}$ $\mathrm{g}^{-1} ; \mathrm{o}-\mathrm{LF}_{200}=2.5 \pm 0.1$ vs. $0.3 \pm 0.1 \mathrm{mg} \mathrm{C} \mathrm{g}^{-1}$ ). The mass of SOC in the HF were also nearly twice as high in the $\mathrm{CaCO}_{3}$-bearing site $(45.5 \pm 0.6 \mathrm{mg} \mathrm{C}$ $\left.\mathrm{g}^{-1}\right)$, relative to the $\mathrm{CaCO}_{3}$-free site $(23.1 \pm 0.6 \mathrm{mg} \mathrm{C}$ reported $I$ and $R$ index scores, seen in a geochemically- and pedoclimatically diverse dataset, have been plotted as reference lines in red (see Sebag et al. 2016 for more details). See Suppl. Fig. 6 for the direct comparison of results from this study with data from other Swiss soils (Matteodo et al. 2018)

$\mathrm{g}^{-1}$ ), demonstrating that soil samples with an increased $\mathrm{Ca}$ prevalence contained more mineralassociated SOC.

\section{$\delta^{13} C$ values of fractions}

The $\delta^{13} \mathrm{C}$ values of the $\mathrm{LFs}$ at the $\mathrm{CaCO}_{3}$-bearing site were always higher than those at the $\mathrm{CaCO}_{3}$-free site (f-LF $=-25.9 \pm 0.2 \%$ vs. $\quad-27.2 \pm 0.1 \%$; o- $-\mathrm{LF}_{10}=-26.5 \pm 0.2 \%$ vs. $-27.9 \pm 0.1 \%$; o- $-\mathrm{LF}_{200}=-25.8 \pm 0.2 \%$ vs. $\quad-27.6 \pm 0.1$, respectively; Fig. 5; Suppl. Fig. S9). Yet, $\delta^{13} \mathrm{C}$ values of the $\mathrm{HF}$ were typically lower at the $\mathrm{CaCO}_{3}$-bearing site than at the $\mathrm{CaCO}_{3}$-free site, which was particularly evident in B1 or B2, but less apparent in B3 (Fig. 6). Thus, the $\mathrm{CaCO}_{3}$-free site displayed an increase in $\delta^{13} \mathrm{C}$ values from the LFs to the $\mathrm{HF}$, but the $\delta^{13} \mathrm{C}$ values of the $\mathrm{LFs}$ were similar to the $\mathrm{HF}$ at the $\mathrm{CaCO}_{3}$ bearing site (Fig. 5).

There were small differences between the $\delta^{13} \mathrm{C}$ values of the bulk and $\mathrm{HF}$, with a slight loss of the depth trend, which could in part be explained by the higher proportions of LF material in surficial samples. To check our trends, measurements of $\delta^{13} \mathrm{C}$ values in bulk and HF samples were repeated after some weeks (newly prepared elemental analyser reactor). Results showed a slightly higher variance than was observed 
$\mathrm{CaCO}_{3}$-free site

A
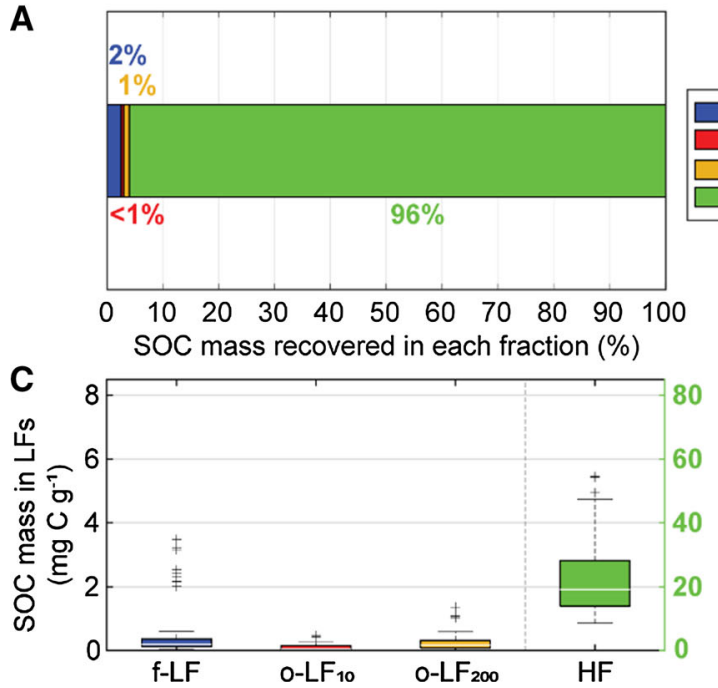

Fig. 4 a and $\mathbf{b}$ Average proportion of SOC mass recovered in the fractions (free-light, occluded light fractions separated at 10 and $200 \mathrm{~J} \mathrm{~mL}^{-1}$, and heavy fractions; f-LF, o- $\mathrm{LF}_{10}, \mathrm{o}-\mathrm{LF}_{200}$, $\mathrm{HF}$, respectively) from the $\mathbf{a} \mathrm{CaCO}_{3}$-free and $\mathbf{b} \mathrm{CaCO}_{3}$-bearing site as a percent of total SOC mass. $\mathbf{c}$ and Mass of soil organic carbon (SOC) recovered in the light fractions (LFs; left y axis) and $\mathrm{HF}$ (right y axis) from $1 \mathrm{~g}$ of oven-dried $\left(105^{\circ} \mathrm{C}\right)$ soil $(\mathrm{mg} \mathrm{C}$
$\mathrm{CaCO}_{3}$-bearing site

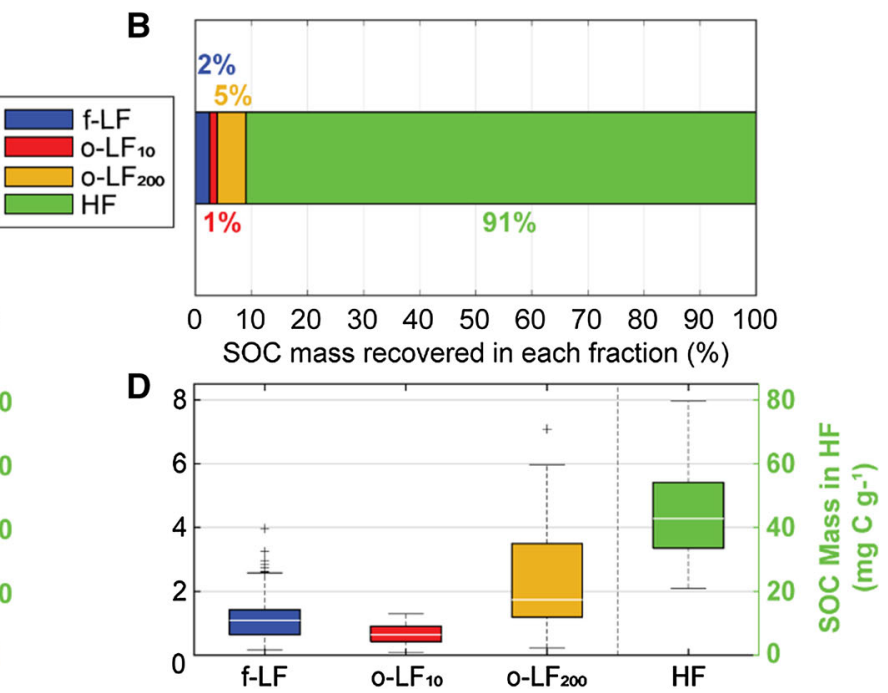

$\mathrm{g}^{-1}$ ) at the $\mathbf{c} \mathrm{CaCO}_{3}$-free and $\mathbf{d ~} \mathrm{CaCO}_{3}$-bearing site. Bottom and top edges of the boxes in the box plot represent the 25th and 75th percentiles, the middle bars represent the median. Whiskers represent the range of data points not considered as outliers, while ' + ' represent values outside of the maximum potential whisker value, corresponding to $\pm 0.4 \mathrm{SE}$ of the mean (outliers)

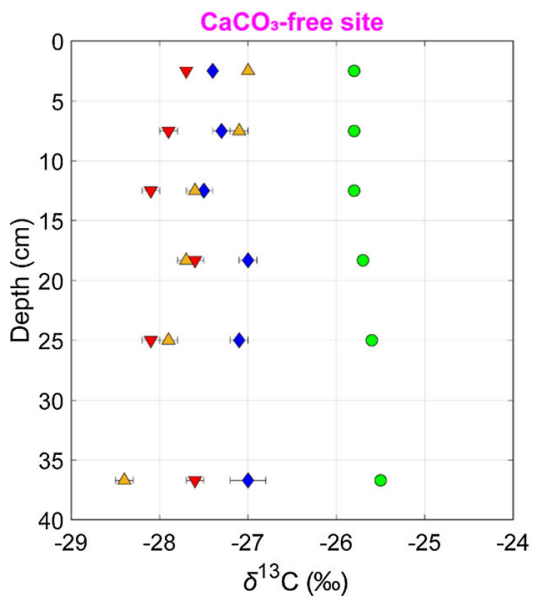

Fig. 5 Mean carbon isotope compositions $\left(\delta^{13} \mathrm{C}\right.$ values) of the fractions (free-light, occluded light fractions separated at 10 and $200 \mathrm{~J} \mathrm{~mL}^{-1}$, and heavy fractions; f-LF, o- $\mathrm{LF}_{10}, \mathrm{o}-\mathrm{LF}_{200}$, HF, respectively) with sample depth $(\mathrm{cm})$. The symbols represent the mean, the bars the standard error of the mean (SE) of triplicate

between our triplicate measurements. Ultimately, this uncertainty reduced the magnitude of variation in the DF $\delta^{13} \mathrm{C}$ values with depth, relative to the bulk $\delta^{13} \mathrm{C}$ values.

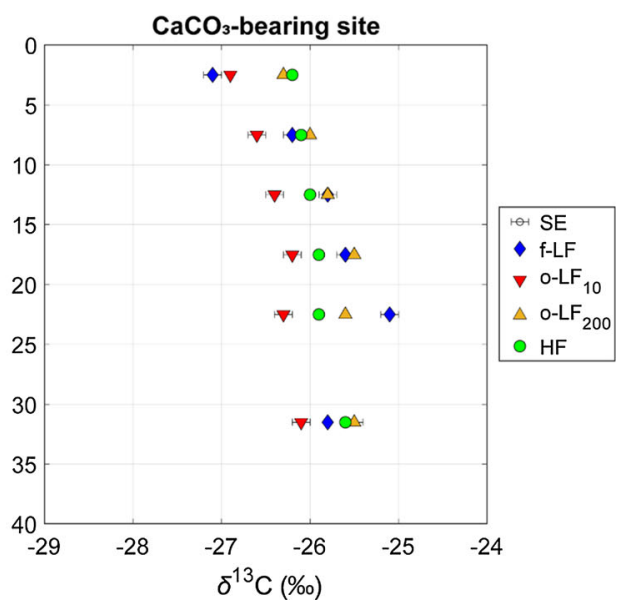

measurements of the $\delta^{13} \mathrm{C}$ values from the $\mathrm{CaCO}_{3}$-free $(\mathrm{F} 1, \mathrm{~F} 2$, $\mathrm{F} 3$ ) sites on the left and the $\mathrm{CaCO}_{3}$-bearing sites $(\mathrm{B} 1, \mathrm{~B} 2, \mathrm{~B} 3)$ on the right. Depth profiles of $\delta^{13} \mathrm{C}$ values for individual profiles can be found in Suppl. Fig. S9

\section{XPS characterisation of fractions}

Surficial chemical compositions The two main elements detected by XPS were C (44-57\%) and oxygen $(\mathrm{O}, 30-40 \%)$. The high $\mathrm{C}$ contents were likely 


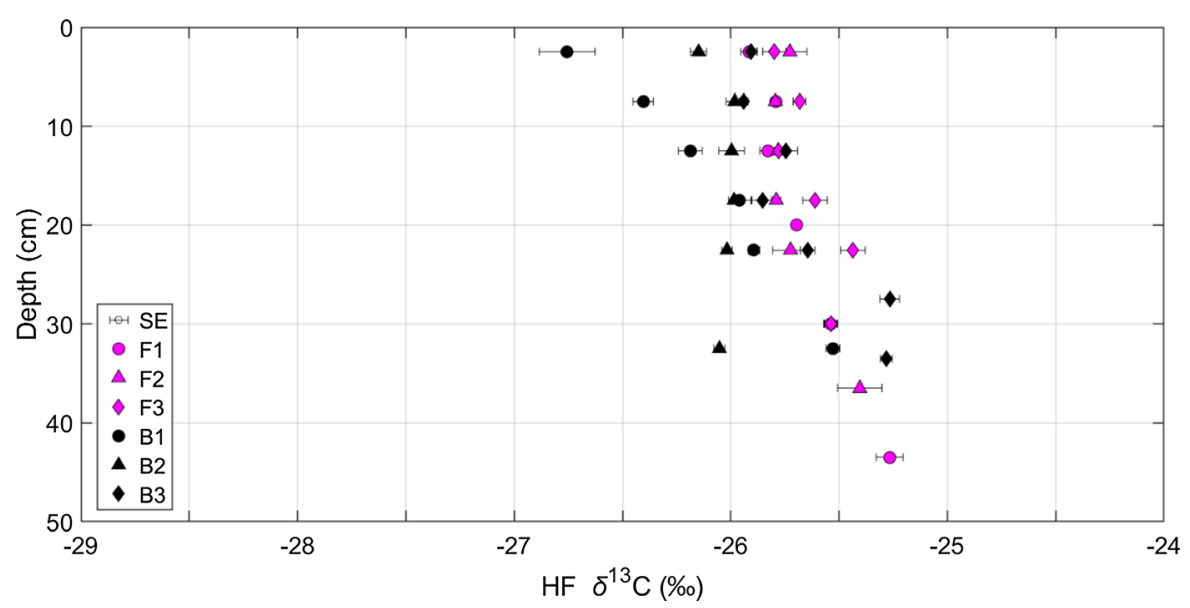

Fig. 6 Mean carbon isotope compositions $\left(\delta^{13} \mathrm{C}\right.$ values) of the heavy fractions (HF) from the $\mathrm{CaCO}_{3}$-free $(\mathrm{F} 1, \mathrm{~F} 2, \mathrm{~F} 3)$ and $\mathrm{CaCO}_{3}$-bearing (B1, B2, B3) profiles at different depths $(\mathrm{cm})$.

caused by the adsorption of adventitious $\mathrm{C}$ by the samples. As a result, the surficial composition of the fractions were not reliable (Suppl. Table S2). Elements associated with the mineral or organic phases (e.g. $\mathrm{N}, \mathrm{Ca}, \mathrm{Fe}, \mathrm{Si}, \mathrm{Ti}$, or $\mathrm{Al}$ ) were all detected at low contents. Tungsten and chlorine were also detected at low contents, representing residues of SPT used for fractionation and chlorides from $\mathrm{HCl}-$ fumigation, respectively.

Patterns in XPS survey scans While quantification of the surficial chemical composition of the fractions were unreliable, information could still be drawn from the differences in bonding environments of surficial elements inferred from the XPS scans (Suppl. Fig. S2 \& S10-S13). There was a slight shift in the $\mathrm{N}_{1 \mathrm{~s}}$ peak towards more protonated $\mathrm{N}$ forms at the more acidic $\mathrm{CaCO}_{3}$-free site (Suppl. Fig. S13). Calcium metatungstate precipitation was not evident on the details of the $\mathrm{W}_{4 \mathrm{f}}$ scans (Suppl. Fig. S2). There was also a clear difference in the $\mathrm{Ca}_{2 p}$ signal between the sites (Fig. 7a, b). Both sites presented a peak in the $\mathrm{Ca}_{2 \mathrm{P} 1 / 2}$ region, but this peak was better defined in the $\mathrm{CaCO}_{3}$-bearing fractions. Furthermore, the $\mathrm{CaCO}_{3}$ bearing site also displayed a satellite peak in the $\mathrm{Ca}_{2 \mathrm{P} 3 /}$ ${ }_{2}$ region, which was not present at the $\mathrm{CaCO}_{3}$-free site.

$C_{1 s}$ peak deconvolution The deconvolution of the $\mathrm{C}_{1 \mathrm{~s}}$ peak indicated that the largest proportions of surficial $\mathrm{C}$ were always associated with aliphatic /
Error bars represent the standard error of the mean (SE) of triplicate measurements

aromatic C moieties at both sites (Fig. 7; Table 1; Suppl. Fig. S11). The main difference between our sites was a higher proportion of carbonyl $\mathrm{C}$ moieties (288 eV; Fig. 7) in the $\mathrm{CaCO}_{3}$-bearing fractions $(14 \pm 1.1 \%)$ than the $\mathrm{CaCO}_{3}$-free $(9.8 \pm 1.3 \%)$. There were also noticeable increases in the proportion of aliphatic/aromatic $\mathrm{C}$ moieties in the occluded fractions at the $\mathrm{CaCO}_{3}$-free site. The ratios of aliphatic/aromatic $\mathrm{C}$ to oxidised $\mathrm{C}$ moieties in the LFs were typically higher and more similar between fractions at the $\mathrm{CaCO}_{3}$-bearing site. Yet, the ratios in the $\mathrm{HF}$ were higher at the $\mathrm{CaCO}_{3}$-bearing site and decreased with depth.

\section{Discussion}

In this study, we aimed to evaluate the relative importance of different processes in the accumulation of SOC at two otherwise-similar sites, with or without $\mathrm{CaCO}_{3}$. Attempting to find soils that had developed under highly similar soil forming conditions with a varied $\mathrm{Ca}$ prevalence, we retained only six profiles, which were all in close proximity $(<500 \mathrm{~m})$. More details on the geochemical similarities between these sites can be found in Rowley et al. (2020). Generalisation of the findings from this study to other soils under different environmental conditions is not supported by our experimental layout; yet mechanistic 

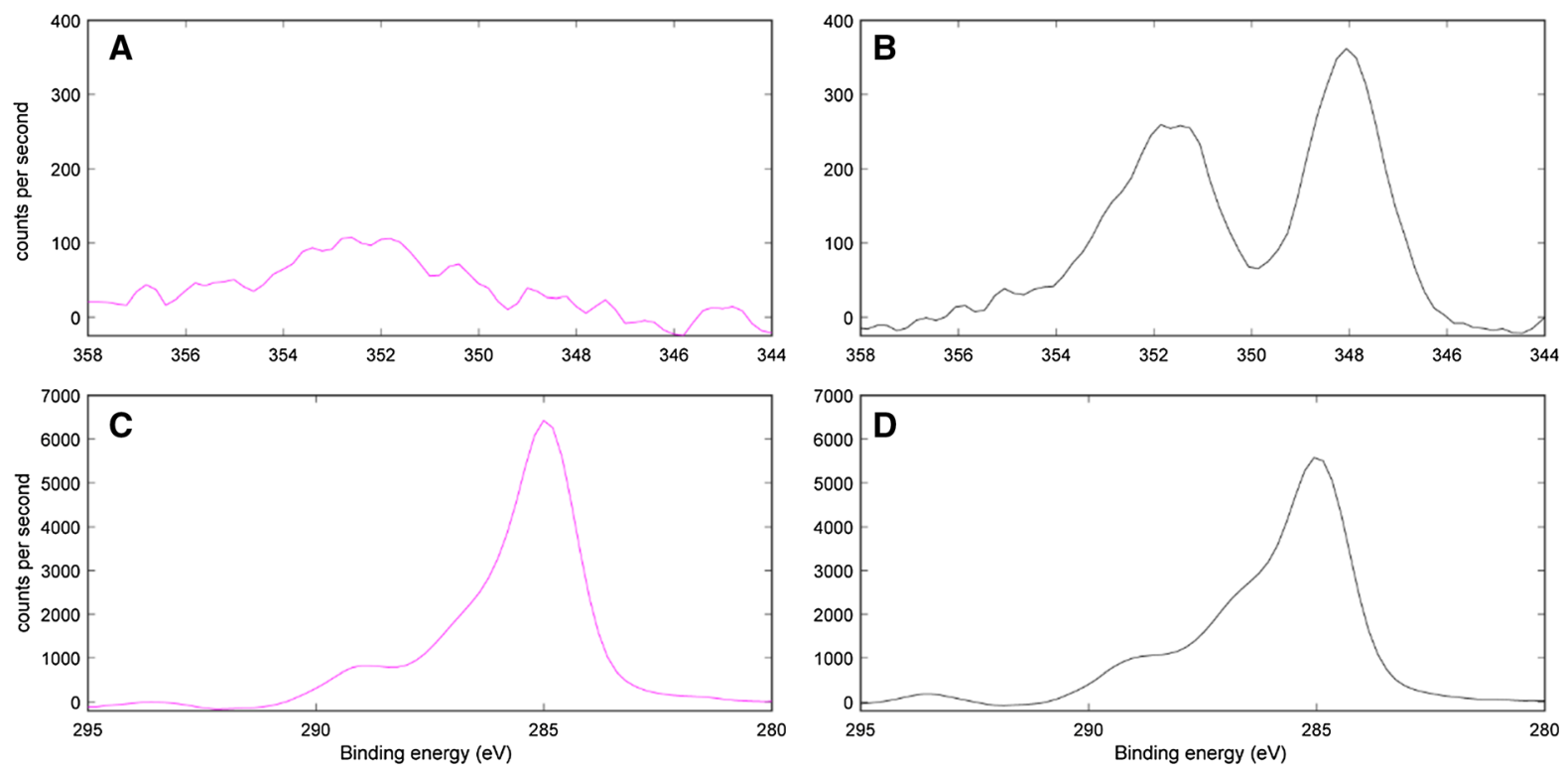

Fig. 7 X-ray photoelectron spectroscopy (XPS) spectra in the $\mathrm{Ca}_{2 \mathrm{p}}(\mathbf{a}$ and $\mathbf{b})$ and $\mathrm{C}_{1 \mathrm{~s}}$ (c and $\left.\mathbf{d}\right)$ binding energy $(\mathrm{eV})$ range of the sample subset from the $\mathrm{CaCO}_{3}$-free (F2.1 \& F2.4; a and c) and

$\mathrm{CaCO}_{3}$-bearing (B2.1 \& B2.4; b and d) site. See Suppl. Fig. S10 $\left(\mathrm{Ca}_{2 \mathrm{p}}\right)$ and Suppl. Fig. $\mathrm{S} 11\left(\mathrm{C}_{1 \mathrm{~s}}\right)$ for individual XPS spectra from each fraction

Table 2 Results obtained from the deconvolution of the carbon $1 \mathrm{~s}\left(\mathrm{C}_{1 \mathrm{~s}}\right) \mathrm{X}$-ray photoelectron spectra for the fractions (freelight, occluded light fractions separated at $10 \mathrm{~J} \mathrm{~mL}^{-1}$ and $200 \mathrm{~J}$

$\mathrm{mL}^{-1}$, and heavy fractions; f-LF, o-LF $10, \mathrm{o}-\mathrm{LF}_{200}, \mathrm{HF}$, respectively) from the $\mathrm{CaCO}_{3}$-free $(\mathrm{F} 2.1 \& \mathrm{~F} 2.4)$ and $\mathrm{CaCO}_{3}$ bearing (B2.1 \& B2.4) sample subset

\begin{tabular}{|c|c|c|c|c|c|c|}
\hline Sample & Fractions & $\begin{array}{l}\mathrm{C}-\mathrm{C} / \mathrm{C}-\mathrm{H} \\
285 \mathrm{eV}\end{array}$ & $\begin{array}{l}\mathrm{C}-\mathrm{O} \\
286.5 \mathrm{eV}\end{array}$ & $\begin{array}{l}\mathrm{C}=\mathrm{O} \\
288 \mathrm{eV}\end{array}$ & $\begin{array}{l}\mathrm{O}-\mathrm{C}=\mathrm{O} \\
289.5 \mathrm{eV}\end{array}$ & $\begin{array}{l}\text { Ratio of } \mathrm{C}-\mathrm{C}-\mathrm{C}-\mathrm{H} \\
\text { to oxidised } \mathrm{C} \\
(\mathrm{C}-\mathrm{O} / \mathrm{C}=\mathrm{O} / \mathrm{O}-\mathrm{C}=\mathrm{O})\end{array}$ \\
\hline \multirow[t]{4}{*}{ F2.1 } & f-LF & 57.6 & 24.1 & 13.4 & 4.9 & 0.74 \\
\hline & $\mathrm{o}-\mathrm{LF}_{10}$ & 73.8 & 11.6 & 8.3 & 6.2 & 0.35 \\
\hline & o- $\mathrm{LF}_{200}$ & 70.4 & 16.7 & 7.6 & 5.3 & 0.42 \\
\hline & $\mathrm{HF}$ & 48.3 & 29.1 & 13.2 & 9.4 & 1.07 \\
\hline \multirow[t]{4}{*}{$\mathrm{F} 2.4$} & f-LF & 59.2 & 23.7 & 11.2 & 5.8 & 0.69 \\
\hline & $\mathrm{o}-\mathrm{LF}_{10}$ & 71.7 & 14.1 & 7.6 & 6.5 & 0.39 \\
\hline & $\mathrm{o}-\mathrm{LF}_{200}$ & 70.1 & 16.5 & 5.4 & 8.0 & 0.43 \\
\hline & $\mathrm{HF}$ & 64.8 & 19.6 & 8.3 & 7.2 & 0.54 \\
\hline \multirow[t]{4}{*}{ B2.1 } & f-LF & 61.6 & 21.0 & 13.3 & 4.1 & 0.62 \\
\hline & o-LF 10 & 59.4 & 22.0 & 12.8 & 5.8 & 0.68 \\
\hline & o- $\mathrm{LF}_{200}$ & 59.1 & 19.3 & 15.0 & 6.7 & 0.69 \\
\hline & $\mathrm{HF}$ & 47.5 & 27.0 & 17.4 & 8.1 & 1.11 \\
\hline \multirow[t]{4}{*}{ B2.4 } & f-LF & 57.6 & 19.0 & 16.7 & 6.7 & 0.74 \\
\hline & $\mathrm{o}-\mathrm{LF}_{10}$ & 63.3 & 20.3 & 10.0 & 6.4 & 0.58 \\
\hline & $\mathrm{o}-\mathrm{LF}_{200}$ & 58.2 & 22.4 & 14.8 & 4.7 & 0.72 \\
\hline & $\mathrm{HF}$ & 55.1 & 25.1 & 10.8 & 9.0 & 0.81 \\
\hline
\end{tabular}

The first four columns represent the percentage area of each sub-peak within the total $\mathrm{C}_{1 \mathrm{~s}}$ spectra and are indicative of different $\mathrm{C}$ bonding environments (listed in Table 2). The final column represents the ratio between the percentages of the sub-peak centred at $285 \mathrm{eV}$ relative to the percentage representation of other sub-peaks 
insights gained from this approach can still inform our understanding of SOC dynamics in Ca-bearing soils.

To analyse the processes involved in the accumulation of SOC, we separated free SOC (f-LF) from occluded (o- $\left.\mathrm{LF}_{10} \& \mathrm{o}-\mathrm{LF}_{200}\right)$ and mineral-associated SOC (HF) using DF and sequential sonication. We then assume that these specific fractions relate to operationally-defined pools of SOC or processes that store organic $\mathrm{C}$ in soils, specifically: f-LF- chiefly plant-derived $\mathrm{OM}$ stored without notable interaction with the soil matrix, o- $\mathrm{LF}_{10}$ — chiefly plant-derived OM trapped within aggregates that have a lower resistance to sonication, $\mathrm{o}-\mathrm{LF}_{200}-\mathrm{OM}$ of both plant and microbial origin stored within aggregates that have a higher resistance to sonication, $\mathrm{HF}$ - relatively small organic molecules of plant and microbial origin, which are adsorbed onto mineral surfaces. It is still possible that within our HF, there are clay- to nanosized aggregates that continue to physically protect SOC from further oxidative transformation, contributing to its accumulation (Vogel et al. 2014). However, at this scale, this stabilisation by physical separation is arguably indistinguishable from the influence of sorption, both in terms of biogeochemical signature and conferred stability, so that these processes may be considered as mutually inclusive (See Fig. 1 in Rowley et al. 2018 for more details). We have also made the assumption that increasing sonication energies disrupt aggregates of increasing tensile strength, accessing occluded SOC pools associated with different types of aggregates (see Kaiser and Berhe 2014 for detailed review). While attribution of these occluded fractions to specific aggregate size classes is not possible, we can reasonably assume that, from differences in their tensile strength, material from the $\mathrm{o}-\mathrm{LF}_{10}$ were stored within aggregates that were more dynamic, relative to the o- $\mathrm{LF}_{200}$.

\section{Ca-mediated occlusion}

As hypothesised, the $\mathrm{CaCO}_{3}$-bearing site had a larger occluded SOC pool, particularly in the o- $\mathrm{LF}_{200}$. This larger pool of occluded SOC could be partially explained by the higher SOC content at the $\mathrm{CaCO}_{3}$ bearing site, which is known to positively influence aggregation processes and occlusion (Chenu 1989; Chenu and Cosentino 2011). The presence of $\mathrm{CaCO}_{3}$ and an increased $\mathrm{Ca}$ content $\left(\mathrm{CaCO}_{3}\right.$-bearing site) has also been repeatedly linked to increased aggregation and a larger pool of occluded SOC (Kaiser et al. 2014; Muneer and Oades 1989a; Paradelo et al. 2016). In humid conditions, this is usually attributed to the flocculation of soil separates by exchangeable $\mathrm{Ca}^{2+}$ (Muneer and Oades 1989b), rather than the cementation of aggregates by $\mathrm{CaCO}_{3}$ during its evaporative precipitation (Fernández-Ugalde et al. 2014). Thus, the increased occluded SOC pool at the $\mathrm{CaCO}_{3}$ bearing site was most likely driven by a mixture of biotic (SOC content and microorganism activity) and abiotic (flocculation by exchangeable $\mathrm{Ca}^{2+}$ ) positive influences on aggregation.

Yet, contrary to our hypothesis, the f-LF and occluded pools were of little overall significance to bulk SOC dynamics at either site. Our results indicated that occluded SOC accounted for between 1-3\% and $3-10 \%$ of total SOC at the $\mathrm{CaCO}_{3}$-free and $\mathrm{CaCO}_{3}$ bearing site, respectively. We had also expected that the $\mathrm{CaCO}_{3}$-bearing site may have had a larger proportion of aggregates with a higher tensile strength $\left(\mathrm{o}-\mathrm{LF}_{200}\right)$ in the $\mathrm{B}$ horizon, but there were no significant differences in the ratio of $\mathrm{o}-\mathrm{LF}_{10}$ to $\mathrm{o}-\mathrm{LF}_{200}$ between our sites. Contrastingly, several key studies have repeatedly highlighted the importance of occlusion mediated by $\mathrm{CaCO}_{3}$ to the accumulation of SOC in environments with a low Aridity Index (Blanco-Moure et al. 2012a; Blanco-Moure et al. 2012b; Fernández-Ugalde et al. 2014; FernándezUgalde et al. 2011; Virto et al. 2013). The humid conditions present at the Nant Valley could have reduced the importance of the occluded pool and aggregate tensile strength at the $\mathrm{CaCO}_{3}$-bearing site, by inhibiting the evaporative precipitation of $\mathrm{CaCO}_{3}$ and its cementation of aggregates. Accordingly, using fractionation parameters comparable to ours (sonicated at $300-450 \mathrm{~J} \mathrm{~mL}^{-1}$ for soils with a loamy texture and density cut-off of $1.6 \mathrm{~g} \mathrm{~cm}^{-3}$ ), Schrumpf et al. (2013) demonstrated that, over a larger range of humid soils, the occluded pool also accounted for a small proportion of total SOC (4-17\%).

A higher sonication energy could have been expected to slightly increase the recovery in our occluded fractions (Kaiser and Berhe 2014; Schmidt et al. 1999). Furthermore, preliminary testing showed that differences in recovery were negligible at higher sonication energies $\left(<590 \mathrm{~J} \mathrm{~mL}^{-1}\right)$ in our silty-loam textured soils. Furthermore, a higher density cut-off for our fractionation method would have likely increased recovery in the occluded fractions as was 
recently seen in Vormstein et al. $\left(2020 ;>1.8 \mathrm{gcm}^{-3}\right)$; but, this may have also increased mineral contamination in the LFs. Thus, evidence provided by our study implies that $\mathrm{Ca}$-mediated occlusion may not be as important to the accumulation of SOC in Ca-rich humid environments as first expected.

A recent study by Yang et al. (2020) investigating mineralisation rates of incubated aggregates from similar humid, grassland, $\mathrm{CaCO}_{3}$-bearing or $\mathrm{CaCO}_{3}$ free soils (Peruvian Andes) may further support this finding. They demonstrated that mineralisation rates for incubated aggregates did not change upon their destruction, and thus, the removal of the physical separation afforded by occlusion (Yang et al. 2020). From this result, Yang et al. (2020) concluded that occlusion/physical separation was less important for the stabilisation of SOC in these humid environments, relative to mineral association. Our results would support their hypothesis and suggest that future studies investigating SOC dynamics in similar Ca-rich and humid soil environments should instead focus on the processes that increase mineral-associated SOC content.

Ca prevalence is linked to an increased mineralassociated SOC content

It was the mineral-associated SOC pool that accounted for the majority of SOC at both sites. Since SOC content was almost twice as high at the $\mathrm{CaCO}_{3}$ bearing site, the mass of mineral-associated SOC was also approximately twice as high. This accumulation of mineral-associated SOC was unlikely to have arisen as a direct result of $\mathrm{CaCO}_{3}$ due in part to the humid conditions at the Nant Valley precluding extensive precipitation of pedogenic carbonates and the low $\mathrm{CaCO}_{3}$ content of the $\mathrm{CaCO}_{3}$-bearing profiles. Yet, we can hypothesise that $\mathrm{CaCO}_{3}$ likely played an indirect role in the accumulation of mineral-associated SOC at our sites, through its cascading influence on soil biogeochemistry (Rowley et al. 2020).

During its dissolution, $\mathrm{CaCO}_{3}$ releases $\mathrm{Ca}^{2+}$ into the soil solution and carbonate equilibria can buffer soil $\mathrm{pH}$. In turn, this $\mathrm{Ca}$ source can influence the crystallinity of $\mathrm{Fe}$ oxides (Thompson et al. 2011). Rowley et al. (2020) indeed reported a higher incidence of poorly crystalline Fe forms (oxalate-todithionite extractable Fe; McKeague and Day 1966) at the studied $\mathrm{CaCO}_{3}$-bearing site. Both this released $\mathrm{Ca}$
(Rasmussen et al. 2018; Rowley et al. 2018) and the higher proportion of poorly crystalline Fe forms (Kramer and Chadwick 2018; Parfitt and Childs 1988) have well-established links to an accumulation of mineral-associated SOC through sorption processes. Yet, the direct role of poorly crystalline $\mathrm{Fe}$ in the sorption and stabilisation of mineral-associated $\mathrm{SOC}$ at the $\mathrm{CaCO}_{3}$-bearing site would have likely been limited by the high soil $\mathrm{pH}$ conditions (Sowers et al. 2018a). As pH increases, the variable surface charge of poorly crystalline Fe forms, like ferrihydrite, shifts towards negative, reducing their interaction with SOC functional groups and increasing their interaction with cations, like $\mathrm{Ca}^{2+}$ (Schwertmann and Fechter 1982; Sowers et al. 2018a). Following this, $\mathrm{Ca}^{2+}$ addition has been shown to increase the sorption of dissolved organic $\mathrm{C}$ by ferrihydrite at higher $\mathrm{pH}$ conditions, beyond its point of zero charge (Sowers et al. 2018b) in Fe-Ca-ternary complexes (Sowers et al. 2018a). This mechanism brings to light the importance of $\mathrm{Ca}^{2+}$ in the interactions between SOC and poorly crystalline $\mathrm{Fe}$ forms in soil environments with a higher $\mathrm{pH}$, like the $\mathrm{CaCO}_{3}$-bearing site.

It is thus likely that the higher $\mathrm{Ca}$ content played a fundamental role in the near-doubling of mineralassociated SOC content at the $\mathrm{CaCO}_{3}$-bearing site, which was likely achieved through cation bridging of organo-mineral associations. Furthermore, we can speculatively hypothesise that due to the persistence of these complexes during fractionation with SPT (high $\mathrm{Na}^{+}$content and cation exchange potential), these interactions are unlikely to have been outer sphere in nature and were instead, most likely inner sphere bridge complexes (Kalinichev and Kirkpatrick 2007; Rowley et al. 2018; Sutton et al. 2005).

The complexation of SOC by calcium

We attempted to use the XPS $\mathrm{C}_{1 \mathrm{~s}}$ and $\mathrm{Ca}_{2 \mathrm{p}}$ spectra (Fig. 7) to investigate the complexation of specific SOC functional groups by $\mathrm{Ca}^{2+}$. The complexation of SOC by $\mathrm{Ca}^{2+}$ has typically been thought to preferentially stabilise phenol and carboxyl functional groups (Kaiser 1998; Römkens and Dolfing 1998). The main difference between our sites in the XPS $C_{1 s}$ peak deconvolution was an increased proportion of carbonyl $\mathrm{C}$ moieties at the $\mathrm{CaCO}_{3}$-bearing site. Speculatively, this may be caused by a shift in the $\mathrm{C}_{1 \mathrm{~s}}$ spectra upon complexation of carboxyl functional groups by 
$\mathrm{Ca}$, as witnessed by Demri and Muster (1995; $\mathrm{Ca}[\mathrm{COOH}]_{2}$ closer to $288.6 \mathrm{eV}$ than $289.5 \mathrm{eV}$; Table 2). Similar shifts in the $C_{1 s}$ spectra upon complexation by different metals have indeed been previously reported in X-ray absorption spectra (De Stasio et al. 2005; Plaschke et al. 2005). However, more in-depth analyses with XPS or synchrotronbased spectroscopy (see Prietzel et al. 2020 for more details) would be required to investigate this hypothesis as the $\mathrm{Ca}_{2 \mathrm{p}}$ spectra could not provide supporting evidence.

There were two peaks present in the $\mathrm{Ca}_{2 \mathrm{p}}$ spectra at the $\mathrm{CaCO}_{3}$-bearing site, but only one weaker peak present at the $\mathrm{CaCO}_{3}$-free site (Fig. 7). Unfortunately, this peak could not be accurately identified by XPS as there is only a small range of chemical shifts in the $\mathrm{Ca}_{2 \mathrm{p}}$ spectra (<1 eV; Moulder and Chastain 1992) and XPS data on Ca-rich soil samples has not been widely reported in the literature (Boiteau et al. 2020; Demri and Muster 1995). We can clearly state that the peaks in our $\mathrm{Ca}_{2 \mathrm{p}}$ region were not related to $\mathrm{CaCO}_{3}$, since it had been quantitatively removed by the $\mathrm{HCl}$ fumigation. Boiteau et al. (2020) recently attributed similar peaks to $\mathrm{Ca}-\mathrm{O}-\mathrm{C}$ bonds and $\mathrm{Ca}$-plagioclase. Speculatively, the $\mathrm{Ca}_{2 \mathrm{p} 3 / 2}$ peak at the $\mathrm{CaCO}_{3}$-bearing site is also likely linked to similar $\mathrm{Ca}-\mathrm{O}-\mathrm{C}$ bonds, inherent Ca-bound within particulate $\mathrm{OM}$, and potentially some Ca-plagioclase (Boiteau et al. 2020; Rowley et al.2020). More advanced spectroscopic methods are now required to confirm this hypothesis and identify whether inner sphere complexes mediated by $\mathrm{Ca}^{2+}$ are indeed responsible for the increased mineral-associated SOC content of these soils.

Organic matter quality

\section{Bulk soil differences}

Bulk $\delta^{13} \mathrm{C}$ values were lower at the $\mathrm{CaCO}_{3}$-bearing site relative to the $\mathrm{CaCO}_{3}$-free site, even though vegetation $\delta^{13} \mathrm{C}$ values were largely invariant (Fig. 2). Furthermore, while the $\mathrm{CaCO}_{3}$-bearing site had a lower proportion of A5 contribution to the S2 thermogram (most-thermally stable SOC), it also had lower I Index scores in the B horizons (less thermally stable; Fig. 3). This suggests that there is an accumulation of SOC with a more moderate and homogeneous thermal signature at this site. In contrast, $\mathrm{OM}$ at the $\mathrm{CaCO}_{3}$-free site had a relatively higher proportion of compounds with both low and high thermostability. These results contrasted previous results for the Alps, which demonstrated that $\mathrm{CaCO}_{3}$-bearing soils typically had lower $R$ index scores. This contrast could potentially be explained by the scale of our different studies; where, Rock-Eval ${ }^{\circledR}$ analyses may have struggled to identify the differences between SOC at our highly similar sites, relative to the geochemically diverse dataset of Matteodo et al. (2018; Suppl. Fig. S6) or pedoclimatically diverse dataset of Sebag et al. (2016).

Both bulk thermostability (Sebag et al. 2016) and $\delta^{13} \mathrm{C}$ values (Boström et al. 2007) are commonly assumed to increase during decomposition processes in soils; yet these signatures can also be influenced by the composition of specific organic compounds or their preferential stabilisation by the mineral phase, due to polarity or stearic constraints. Therefore, it is reasonable to suggest that the trends we observe are the result of both continued decomposition processes and the preferential stabilisation of specific organic compounds at each site, driven by fundamental differences in their mineralogy and bulk geochemistry. Based on our data, we can hypothesise that active decomposition and mineralisation processes were operant at the $\mathrm{CaCO}_{3}$-free site; which meant that OM composition was dominated either by relatively fresh plant material that had not yet fully entered the decomposition continuum or highly decomposed residues from active decomposition and mineralisation processes. This would result in a thermal signature with a relatively increased presence of thermally labile compounds (high I index), but also thermally stable compounds representing advanced decomposition residues (A5; Malou et al. 2020). This proposition is also consistent with the observation that the bulk SOC contents were lower and the $\delta^{13} \mathrm{C}$ values were higher at the $\mathrm{CaCO}_{3}$-free site. On the other hand, at the $\mathrm{CaCO}_{3}$-bearing site, the intensity of decomposition processes might have been inhibited by $\mathrm{Ca}^{2+}$; which may have mediated a preferential stabilisation of organic compounds with $\delta^{13} \mathrm{C}$ values that are indicative of slight oxidative transformation and a moderate thermostability.

Differences in the microbial community composition, activity, or abundance were not measured at the Nant Valley. Microorganism communities have different biogeochemical mechanisms for the oxidative transformation of SOC or the utilisation of $\mathrm{Ca}$; which 
in turn, drive variations in their $\mathrm{C}$ use efficiency, the partitioning of $\mathrm{C}$ between microbial biomass and respiration (Bradford and Crowther 2013), or the stability of Ca minerals or complexes (Gadd 2010). Soil $\mathrm{pH}$, which increased from the $\mathrm{CaCO}_{3}$-free to the $\mathrm{CaCO}_{3}$-bearing site, is known to act as a 'master variable' in soils, and an increase in $\mathrm{pH}$ is linked to shifts in microbial community composition (decreasing fungal to bacterial ratio) and/or functioning(Bahram et al. 2018; Blagodatskaya and Anderson 1999; Rousk et al. 2010; Rousk et al. 2009). Soares and Rousk (2019) recently demonstrated that $\mathrm{C}$ use efficiency had an exponential negative relationship with the fungal to bacterial ratio. It can be hypothesised that an increase in $\mathrm{pH}$ at our $\mathrm{CaCO}_{3}$-bearing sites may have been linked to a decrease in the fungal-to-bacterial ratio (Bahram et al. 2018; Blagodatskaya and Anderson 1999; Rousk et al. 2010; Rousk et al. 2009). Hypothetically, this shift may have increased carbon use efficiency at the $\mathrm{CaCO}_{3}$-bearing site, which would have caused an accumulation of SOC as microbial biomass and necromass (Bahram et al. 2018; Rousk et al. 2010; Rousk et al. 2009). Future studies should investigate how variations in Ca content can influence microbial communities, their carbon use efficiency, and its influence on SOC accumulation or quality.

\section{Similar $\delta^{13} C$ values in the $H F$ and $L F$}

At the $\mathrm{CaCO}_{3}$-free site, $\delta^{13} \mathrm{C}$ values of the $\mathrm{LFs}$ were lower than the HF (Fig. 5), displaying a typical shift from less to more oxidatively transformed $\mathrm{C}$ moving from particulate $\mathrm{OM}$ to mineral-associated SOC, respectively (Poeplau et al. 2017; Schrumpf et al. 2013). This contrasted with the $\mathrm{CaCO}_{3}$-bearing site where $\delta^{13} \mathrm{C}$ values were similar between the LFs and HF (Fig. 5). As described in "Materials and methods", this is unlikely to have arisen due to the precipitation of $\mathrm{Ca}$ metatungstate. Instead, as our sites have developed under similar soil forming conditions, these differences can likely be linked to the variation in $\mathrm{Ca}$ content.

In a recent study, Martí-Roura et al. (2019) used a size fractionation method on $\mathrm{CaCO}_{3}$-free and $\mathrm{CaCO}_{3}$ bearing Mediterranean soils. Similar to our findings with $\mathrm{DF}$, they demonstrated that $\mathrm{CaCO}_{3}$-bearing soils displayed a smaller shift in $\delta^{13} \mathrm{C}$ values between the coarse and fine size fractions (Martí-Roura et al.
2019). It therefore seems that the similarity between different fractions at $\mathrm{CaCO}_{3}$-bearing sites could be independent of fractionation scheme and is instead related to a natural process. The $\delta^{13} \mathrm{C}$ values of the fractions insinuated that the LFs were more oxidatively transformed at the $\mathrm{CaCO}_{3}$-bearing site, but the HF were less oxidatively transformed (Fig. 5). This hypothesis is in accordance with the bulk Rock-Eval ${ }^{\circledR}$ measurements, in which the $\mathrm{CaCO}_{3}$-bearing site contained more moderately thermostable $\mathrm{OM}$ and the $\mathrm{CaCO}_{3}$-free site contained both less- and the mostthermally stable OM. These observations provide further support for the hypothesis that there was a preferential stabilisation of SOC with lower $\delta^{13} \mathrm{C}$ values and moderate thermostability in the mineral or finer-size fractions of soils with an increased $\mathrm{Ca}$ prevalence.

The decomposition continuum in Ca-rich soils

We can thus speculate that together, the bulk RockEval $^{\circledR}$ signatures, similarity between LFs and HF $\delta^{13} \mathrm{C}$ values (Fig. 5), and increased HF SOC content at the $\mathrm{CaCO}_{3}$-bearing site may all support the Decomposition Continuum model in Ca-rich soils (Kleber and Lehmann 2019; Lehmann and Kleber 2015). According to this model, oxidative transformation by microorganisms increases the proportion of negatively-charged functional groups in SOC, which subsequently increases its reactivity towards minerals or cations (Lehmann and Kleber 2015). During the complexation of these functional groups through cation bridging processes, $\mathrm{Ca}^{2+}$ could be preferentially preserving SOC that had already passed a certain level of oxidative transformation at the $\mathrm{CaCO}_{3}$ bearing site. Once this level of oxidative transformation was achieved, SOC functional groups could be complexed by $\mathrm{Ca}^{2+}$. Thereafter, complexation processes with $\mathrm{Ca}^{2+}$ seem to inhibit the complete mineralisation of SOC, causing an accumulation of slightly oxidatively transformed SOC in the mineralassociated fraction of soils with a larger Ca prevalence $\left(\mathrm{CaCO}_{3}\right.$-bearing). More investigation is now required to confirm this hypothesis and further probe the complexation of SOC by $\mathrm{Ca}^{2+}$ in different soil environments, increasing our understanding of the mechanisms and kinetics of these interactions. 


\section{Conclusions}

To isolate the complex role of $\mathrm{Ca}$ in SOC accumulation, we performed a fractionation study on soils which had formed under similar conditions but were either $\mathrm{CaCO}_{3}$-bearing or $\mathrm{CaCO}_{3}$-free. Bulk SOC was twice as high at the $\mathrm{CaCO}_{3}$-bearing profiles, which also had lower $\delta^{13} \mathrm{C}$ values and a moderate thermostability. Occluded SOC pools were larger at the $\mathrm{CaCO}_{3}$ bearing site but were of little overall significance to bulk SOC dynamics at either of our sites. It was instead the HF that accounted for most of the total organic $\mathrm{C}$. The HF thus contained almost twice as much $\mathrm{SOC}$ at the $\mathrm{CaCO}_{3}$-bearing site, establishing that soils with an increased Ca prevalence had a two-fold increase in mineral-associated SOC storage, relative to similar soils with less $\mathrm{Ca}$.

The $\delta^{13} \mathrm{C}$ values of the density fractions from samples at the $\mathrm{CaCO}_{3}$-free site displayed a typical increase from less to more processed OM between the LFs and HF, respectively. This contrasted with the $\mathrm{CaCO}_{3}$-bearing site, which had similar $\delta^{13} \mathrm{C}$ values in the HF and LFs. Both these similarities between the LFs and HF, and the accumulation of mineralassociated SOC at the $\mathrm{CaCO}_{3}$-bearing site were most likely driven by the preferential complexation of SOC in organo-mineral associations mediated by $\mathrm{Ca}$. Through increasing the relative proportion of negatively-charged functional groups, decomposition may actually increase the propensity of SOC to be stabilised through complexation with $\mathrm{Ca}$; thereby, preventing its complete mineralisation and causing it to accumulate in the mineral-associated fraction of soils with an increased $\mathrm{Ca}$ prevalence $\left(\mathrm{CaCO}_{3}\right.$-bearing). Future investigations should now investigate $\mathrm{Ca}-$ mediated complexation processes, how they may be applied to increase global SOC stocks (Minasny et al. 2017), and their potential interactions with management practices that aim to sequester $\mathrm{C}$ inorganically (Beerling et al. 2020).

Acknowledgements Open Access funding provided by Université de Lausanne. Special thanks to Prof. Markus Kleber, Dr. Frank Hagedorn, and Prof. Jasquelin Peña for the detailed discussion on this manuscript during my defence meeting. Thanks to Prof. Thierry Adatte for running our bulk Rock-Eval $^{\circledR}$ samples, Dr. Magali Matteodo for creating a reference dataset, and Dr. David Sebag for transforming them, discussions about the method, and the results. Thanks to Dr. Pierre Mettraux for measuring our XPS samples and for discussions about the method. Thanks also to Dr. Pascal
Vittoz, Dr. Peter Nico, and Prof. Torsten Vennemann for discussions regarding vegetation at the Nant Valley, shifts in various spectra upon complexation, SOC $\delta^{13} \mathrm{C}$ values and their evolution within a soil profile, respectively.

Funding Open Access funding provided by Université de Lausanne.. Funding for this research came from the Canton of Vaud, Swiss National Science Foundation, and the Université de Lausanne.

Data availability We have been fully transparent with our data and materials, including four separate tables in the supplementary information. There is no code to be made available, but we have fully detailed our techniques in "Materials and methods".

\section{Declarations}

Conflict of interest The authors have no conflicts of interests.

Open Access This article is licensed under a Creative Commons Attribution 4.0 International License, which permits use, sharing, adaptation, distribution and reproduction in any medium or format, as long as you give appropriate credit to the original author(s) and the source, provide a link to the Creative Commons licence, and indicate if changes were made. The images or other third party material in this article are included in the article's Creative Commons licence, unless indicated otherwise in a credit line to the material. If material is not included in the article's Creative Commons licence and your intended use is not permitted by statutory regulation or exceeds the permitted use, you will need to obtain permission directly from the copyright holder. To view a copy of this licence, visit http://creativecommons.org/licenses/by/4.0/.

\section{References}

Austin N, Evans B, Herwegh M, Ebert A (2008) Strain localization in the Morcles nappe (Helvetic Alps, Switzerland). Swiss J Geosci 101(2):341-360

Bahram M, Hildebrand F, Forslund SK, Anderson JL, Soudzilovskaia NA, Bodegom PM, Bengtsson-Palme J, Anslan S, Coelho LP, Harend H, Huerta-Cepas J, Medema MH, Maltz MR, Mundra S, Olsson PA, Pent M, Põlme S, Sunagawa S, Ryberg M, Tedersoo L, Bork P (2018) Structure and function of the global topsoil microbiome. Nature 560(7717):233-237

Barreto MSC, Elzinga EJ, Ramlogan M, Rouff AA, Alleoni LRF (2020) Calcium enhances adsorption and thermal stability of organic compounds on soil minerals. Chem Geol, 119804.

Beerling DJ, Kantzas EP, Lomas MR, Wade P, Eufrasio RM, Renforth P, Sarkar B, Andrews MG, James RH, Pearce CR, Mercure J-F, Pollitt H, Holden PB, Edwards NR, Khanna M, Koh L, Quegan S, Pidgeon NF, Janssens IA, Hansen J, Banwart SA (2020) Potential for large-scale CO2 removal 
via enhanced rock weathering with croplands. Nature 583(7815):242-248

Blagodatskaya EV, Anderson T-H (1999) Adaptive responses of soil microbial communities under experimental acid stress in controlled laboratory studies. Appl Soil Ecol 11(2-3):207-216

Blanco-Moure N, Angurel LA, Moret-Fernández D, López MV (2012a) Tensile strength and organic carbon of soil aggregates under long-term no tillage in semiarid Aragon (NE Spain). Geoderma 189-190:423-430

Blanco-Moure N, Moret-Fernández D, López MV (2012b) Dynamics of aggregate destabilization by water in soils under long-term conservation tillage in semiarid Spain. CATENA 99:34-41

Blankinship J, Berhe A, Crow S, Druhan J, Heckman K, Keiluweit M, Lawrence C, Marin-Spiotta E, Plante A, Rasmussen C, Schädel C, Schimel J, Sierra C, Thompson A, Wagai R, Wieder W (2018) Improving understanding of soil organic matter dynamics by triangulating theories, measurements, and models. Biogeochemistry 140:1-13

Boiteau RM, Kukkadapu R, Cliff JB, Smallwood CR, Kovarik L, Wirth MG, Engelhard MH, Varga T, Dohnalkova A, Perea DE, Wietsma T, Moran JJ, Hofmockel KS (2020). Calcareous organic matter coatings sequester siderophores in alkaline soils. Sci Total Environ 138250.

Boström B, Comstedt D, Ekblad A (2007) Isotope fractionation and $13 \mathrm{C}$ enrichment in soil profiles during the decomposition of soil organic matter. Oecologia 153(1):89-98

Bradford MA, Crowther TW (2013) Carbon use efficiency and storage in terrestrial ecosystems. New Phytol 199:7-9. https://doi.org/10.1111/nph.12334

Ceperley N, Zuecco G, Beria H, Carturan L, Michelon A, Penna D, Larsen J, Schaefli B (2020). Seasonal snow cover decreases young water fractions in high Alpine catchments. Hydrol Process

Chenu C (1989) Influence of a fungal polysaccharide, scleroglucan, on clay microstructures. Soil Biol Biochem 21(2):299-305

Chenu C, Cosentino D (2011) Microbial regulation of soil structural dynamics. In: K. Ritz, I.M. Young (Eds.), The architecture and biology of soils: life in inner space. CABI, pp. $37-70$.

Coplen TB (2011) Guidelines and recommended terms for expression of stable-isotope-ratio and gas-ratio measurement results. Rapid Commun Mass Spectrom 25(17):2538-2560

De Stasio G, Schmitt MA, Gellman SH (2005) Spectromicroscopy at the organic-inorganic interface in biominerals. Am J Sci 305(6-8):673

Demri B, Muster D (1995) XPS study of some calcium compounds. J Mater Process Technol 55(3):311-314

Dengis PB, Gerin PA, Rouxhet PG (1995) X-ray photoelectron spectroscopy analysis of biosurfaces: examination of performances with yeast cells and related model compounds. Colloids Surf, B 4(4):199-211

Disnar JR, Guillet B, Keravis D, Di-Giovanni C, Sebag D (2003) Soil organic matter (SOM) characterization by Rock-Eval pyrolysis: scope and limitations. Org Geochem 34(3):327-343

Edwards AP, Bremner JM (1967) Microaggregates in soil. J Soil Sci 18(1):64
Fernández-Ugalde O, Virto I, Barré P, Apesteguía M, Enrique A, Imaz MJ, Bescansa P (2014) Mechanisms of macroaggregate stabilisation by carbonates: implications for organic matter protection in semi-arid calcareous soils. Soil Res 52(2):180-192

Fernández-Ugalde O, Virto I, Barré P, Gartzia-Bengoetxea N, Enrique A, Imaz MJ, Bescansa P (2011) Effect of carbonates on the hierarchical model of aggregation in calcareous semi-arid Mediterranean soils. Geoderma 164(3-4):203-214

Gadd GM (2010) Metals, minerals and microbes: geomicrobiology and bioremediation. Microbiology (Reading) 156(Pt 3):609-643. https://doi.org/10.1099/mic.0.037143-0. https://pubmed.ncbi.nlm.nih.gov/20019082/

Galecki A, Burzykowski T (2015) Linear mixed-effects models using R: a step-by-step approach. Springer, New York

Golchin A, Oades JM, Skjemstad JO, Clarke P (1994) Study of free and occluded particulate organic matter in soils by solid-state c-13 CP/MAS NMR-spectroscopy and scanning electron-microscopy. Aust J Soil Res 32(2):285-309

Grand S, Rubin A, Verrecchia EP, Vittoz P (2016) Variation in soil respiration across soil and vegetation types in an alpine valley. PLoS ONE 11(9):e0163968

Harris D, Horwath WR, van Kessel C (2001) Acid fumigation of soils to remove carbonates prior to total organic carbon or carbon-13 isotopic analysis. Soil Sci Soc Am J 65(6): $1853-1856$

Hasinger O, Spangenberg JE, Millière L, Bindschedler S, Cailleau G, Verrecchia EP (2015) Carbon dioxide in scree slope deposits: a pathway from atmosphere to pedogenic carbonate. Geoderma 247-248:129-139

Hobbie EA, Macko SA, Shugart HH (1999) Insights into nitrogen and carbon dynamics of ectomycorrhizal and saprotrophic fungi from isotopic evidence. Oecologia 118(3):353-360

IUSS Working Group WRB, 2015. World reference base for soil resources 2014, update 2015. No 106. FAO, Rome

Jones E, Singh B (2014) Organo-mineral interactions in contrasting soils under natural vegetation. Front Environ Sci 2(2).

Kaiser K (1998) Fractionation of dissolved organic matter affected by polyvalent metal cations. Org Geochem 28(12):849-854

Kaiser M, Berhe AA (2014) How does sonication affect the mineral and organic constituents of soil aggregates?-A review. J Plant Nutr Soil Sci 177(4):479-495

Kaiser M, Ghezzehei TA, Kleber M, Myrold DD, Berhe AA (2014) Influence of calcium carbonate and charcoal applications on organic matter storage in silt-sized aggregates formed during a microcosm experiment. Soil Sci Soc Am J 78(5):1624-1631

Kalinichev AG, Kirkpatrick RJ (2007) Molecular dynamics simulation of cationic complexation with natural organic matter. Eur J Soil Sci 58(4):909-917

Kleber M, Lehmann J (2019) Humic substances extracted by alkali are invalid proxies for the dynamics and functions of organic matter in terrestrial and aquatic ecosystems. J Environ Qual 48(2):207-216

Kögel-Knabner I, Guggenberger G, Kleber M, Kandeler E, Kalbitz K, Scheu S, Eusterhues K, Leinweber P (2008) Organo-mineral associations in temperate soils: integrating 
biology, mineralogy, and organic matter chemistry. J Plant Nutr Soil Sci 171(1):61-82

Kramer MG, Chadwick OA (2018) Climate-driven thresholds in reactive mineral retention of soil carbon at the global scale. Nat Climate Change 8(12):1104-1108

Lehmann J, Kleber M (2015) The contentious nature of soil organic matter. Nature 528(7580):60-68

Malou OP, Sebag D, Moulin P, Chevallier T, Badiane-Ndour NY, Thiam A, Chapuis-Lardy L (2020) The Rock-Eval ${ }^{\circledR}$ signature of soil organic carbon in arenosols of the Senegalese groundnut basin. How do agricultural practices matter? Agric Ecosyst Environ 301:107030

Martí-Roura M, Hagedorn F, Rovira P, Romanyà J (2019) Effect of land use and carbonates on organic matter stabilization and microbial communities in Mediterranean soils. Geoderma 351:103-115

Matteodo M, Grand S, Sebag D, Rowley MC, Vittoz P, Verrecchia EP (2018) Decoupling of topsoil and subsoil controls on organic matter dynamics in the Swiss Alps. Geoderma 330:41-51

McKeague JA, Day DH (1966) Dithionite- and oxalate-extractable $\mathrm{Fe}$ and $\mathrm{Al}$ as aids in differentiating various classes of soils. Can J Soil Sci 46(1):13-000

Mikutta R, Schaumann GE, Gildemeister D, Bonneville S, Kramer MG, Chorover J, Chadwick OA, Guggenberger G (2009) Biogeochemistry of mineral-organic associations across a long-term mineralogical soil gradient (03-4100kyr) Hawaiian Islands. Geochim Cosmochim Acta 73(7):2034-2060

Minasny B, Malone BP, McBratney AB, Angers DA, Arrouays D, Chambers A, Chaplot V, Chen Z-S, Cheng K, Das BS, Field DJ, Gimona A, Hedley CB, Hong SY, Mandal B, Marchant BP, Martin M, McConkey BG, Mulder VL, O'Rourke S, Richer-de-Forges AC, Odeh I, Padarian J, Paustian K, Pan G, Poggio L, Savin I, Stolbovoy V, Stockmann U, Sulaeman Y, Tsui C-C, Vågen T-G, van Wesemael B, Winowiecki L (2017) Soil carbon 4 per mille. Geoderma 292:59-86

Minick, K.J., Fisk, M.C., Groffman, P.M., 2017. Soil Ca alters processes contributing to $\mathrm{C}$ and $\mathrm{N}$ retention in the $\mathrm{Oa} / \mathrm{A}$ horizon of a northern hardwood forest. Biogeochemistry, $1-15$.

Moulder, J.F., Chastain, J., 1992. Handbook of X-ray photoelectron spectroscopy: A reference book of standard spectra for identification and interpretation of XPS data. Physical Electronics Division, Perkin-Elmer Corporation

Muneer M, Oades JM (1989a) The role of Ca-organic interactions in soil aggregate stability. 2. Field studies with C-14labelled straw, CaCO3 AND CaSO42H2O. Aust J Soil Res 27(2):401-409

Muneer M, Oades JM (1989b) The role of Ca-organic interactions in soil aggregate stability. 3. Mechanisms and models. Aust J Soil Res 27(2):411-423

North PF (1976) Towards an absolute measurement of soil structural stability using ultrasound. J Soil Sci 27(4):451-459

Oades JM (1984) Soil organic matter and structural stability: mechanisms and implications for management. Plant Soil 76(1/3):319-337

Oades JM (1988) The retention of organic matter in soils. Biogeochemistry $5(1): 35-70$
Paradelo R, van Oort F, Barre P, Billiou D, Chenu C (2016) Soil organic matter stabilization at the pluri-decadal scale: Insight from bare fallow soils with contrasting physicochemical properties and macrostructures. Geoderma 275:48-54

Parfitt RL, Childs CW (1988) Estimation of forms of Fe and Al: a review, and analysis of contrasting soils by dissolution and mossbauer methods. Aust J Soil Res 26(1):121-144

Plante AF, Fernández JM, Leifeld J (2009) Application of thermal analysis techniques in soil science. Geoderma 153(1): $1-10$

Plaschke M, Rothe J, Altmaier M, Denecke MA, Fanghänel T (2005) Near edge X-ray absorption fine structure (NEXAFS) of model compounds for the humic acid/actinide ion interaction. $\mathrm{J}$ Electron Spectrosc Relat Phenom 148(3):151-157

Poeplau C, Don A, Six J, Kaiser M, Benbi D, Chenu C, Cotrufo MF, Derrien D, Gioacchini P, Grand S, Gregorich E, Griepentrog M, Gunina A, Haddix M, Kuzyakov Y, Kühnel A, Macdonald L, Soong J, Trigalet S, Nieder R (2018) Isolating organic carbon fractions with varying turnover rates in temperate agricultural soils - A comprehensive method comparison. Soil Biol Biochem 125:10-26

Poeplau C, Vos C, Don A (2017) Soil organic carbon stocks are systematically overestimated by misuse of the parameters bulk density and rock fragment content. SOIL 3(1):61-66

Prietzel J, Klysubun W, Hurtarte LCC (2020) The fate of calcium in temperate forest soils: a Ca K-edge XANES study. Biogeochemistry.

Rasmussen C, Heckman K, Wieder WR, Keiluweit M, Lawrence CR, Berhe AA, Blankinship JC, Crow SE, Druhan JL, Hicks Pries CE, Marin-Spiotta E, Plante AF, Schädel C, Schimel JP, Sierra CA, Thompson A, Wagai R (2018) Beyond clay: towards an improved set of variables for predicting soil organic matter content. Biogeochemistry 137(3):297-306

Römkens PFAM, Dolfing J (1998) Effect of Ca on the solubility and molecular size distribution of DOC and $\mathrm{Cu}$ binding in soil solution samples. Environ Sci Technol 32(3):363-369

Rousk J, Baath E, Brookes PC, Lauber CL, Lozupone C, Caporaso JG, Knight R, Fierer N (2010) Soil bacterial and fungal communities across a $\mathrm{pH}$ gradient in an arable soil. Int Soc Microbial Ecol J 4(10):1340-1351

Rousk J, Brookes PC, Baath E (2009) Contrasting soil pH effects on fungal and bacterial growth suggest functional redundancy in carbon mineralization. Appl Environ Microbiol 75(6):1589-1596

Rovira P, Casals P, Romanyà J, Bottner P, Coûteaux M-M, Ramon Vallejo V (1998) Recovery of fresh debris of different sizes in density fractions of two contrasting soils. Eur J Soil Biol 34(1):31-37

Rowley MC, Grand S, Adatte T, Verrecchia EP (2020) A cascading influence of calcium carbonate on the biogeochemistry and pedogenic trajectories of subalpine soils. Switzerland Geoderma 361:114065

Rowley MC, Grand S, Verrecchia ÉP (2018) Calcium-mediated stabilisation of soil organic carbon. Biogeochemistry 137(1):27-49

Sanderman J, Grandy AS (2020) Ramped thermal analysis for isolating biologically meaningful soil organic matter fractions with distinct residence times. Soil 6(1):131-144 
Satterthwaite FE (1946) An approximate distribution of estimates of variance components. Biometr Bull 2(6):110-114

Schmidt MWI, Rumpel C, Kögel-Knabner I (1999) Evaluation of an ultrasonic dispersion procedure to isolate primary organomineral complexes from soils. Eur J Soil Sci 50(1):87-94

Schrumpf M, Kaiser K, Guggenberger G, Persson T, KoegelKnabner I, Schulze ED (2013) Storage and stability of organic carbon in soils as related to depth, occlusion within aggregates, and attachment to minerals. Biogeosciences 10(3):1675-1691

Schwertmann U, Fechter H (1982) The point of zero charge of natural and synthetic ferrihydrites and its relation to adsorbed silicate. Clay Miner 17(4):471-476

Sebag D, Disnar JR, Guillet B, Di Giovanni C, Verrecchia EP, Durand A (2006) Monitoring organic matter dynamics in soil profiles by "Rock-Eval pyrolysis": bulk characterization and quantification of degradation. Eur J Soil Sci 57(3):344-355

Sebag D, Verrecchia EP, Cécillon L, Adatte T, Albrecht R, Aubert M, Bureau F, Cailleau G, Copard Y, Decaens T, Disnar JR, Hetényi M, Nyilas T, Trombino L (2016) Dynamics of soil organic matter based on new Rock-Eval indices. Geoderma 284:185-203

Soares M, Rousk J (2019) Microbial growth and carbon use efficiency in soil: Links to fungal-bacterial dominance, SOC-quality and stoichiometry. Soil Biol Biochem 131:195-205

Sowers T, Adhikari D, Wang J, Yang Y, Sparks DL (2018a) Spatial associations and chemical composition of organic carbon sequestered in $\mathrm{Fe}, \mathrm{Ca}$, and organic carbon ternary systems. Environ Sci Technol 52(12):6936-6944

Sowers TD, Stuckey JW, Sparks DL (2018b) The synergistic effect of calcium on organic carbon sequestration to ferrihydrite. Geochem Trans 19:4

Sutton R, Sposito G, Diallo MS, Schulten H-R (2005) Molecular simulation of a model of dissolved organic matter. Environ Toxicol Chem 24(8):1902-1911

Thompson A, Rancourt DG, Chadwick OA, Chorover J (2011) Iron solid-phase differentiation along a redox gradient in basaltic soils. Geochim Cosmochim Acta 75(1):119-133

Thoumazeau A, Chevallier T, Baron V, Rakotondrazafy N, Panklang P, Marichal R, Kibblewhite M, Sebag D, Tivet F, Bessou C, Gay F, Brauman A (2020) A new in-field indicator to assess the impact of land management on soil carbon dynamics. Geoderma 375:114496

Torn MS, Trumbore SE, Chadwick OA, Vitousek PM, Hendricks DM (1997) Mineral control of soil organic carbon storage and turnover. Nature 389(6647):170-173
Viret F, Grand S (2019) Combined size and density fractionation of soils for investigations of organo-mineral interactions. J Visual Exp (144).

Virto I, Barré P, Enrique A, Poch RM, Fernández-Ugalde O, Imaz MJ, Bescansa P (2013) Micromorphological analysis on the influence of the soil mineral composition on shortterm aggregation in semi-arid Mediterranean soils. Span J Soil Sci 3(2):116-129

Vittoz P, Gmür P (2008) Introduction aux Journées de la biodiversité dans le Vallon de Nant. In: A.-C.P. Clot, D. Cherix, F. Dessimox, J.-L. Gattolliat, P. Gmür, P. Vittoz, M. Vust (Eds.), Biodiversité du Vallon de Nant Premières Journées de la biodiversité en Suisse romande (5 et 6 juillet, 2008) Mémoire Vol 23. Société vaudoise des Sciences naturelles, Vaud, Switzerland.

Vogel C, Mueller CW, Hoeschen C, Buegger F, Heister K, Schulz S, Schloter M, Kögel-Knabner I (2014) Submicron structures provide preferential spots for carbon and nitrogen sequestration in soils. Nat Commun 5(2947):1-7

Vormstein S, Kaiser M, Piepho HP, Ludwig B (2020) Aggregate formation and organo-mineral association affect characteristics of soil organic matter across soil horizons and parent materials in temperate broadleaf forest. Biogeochemistry 148(2):169-189

Webster R (2007) Analysis of variance, inference, multiple comparisons and sampling effects in soil research. Eur $\mathbf{J}$ Soil Sci 58(1):74-82

Wen L, Li D, Chen H, Wang K (2017) Dynamics of soil organic carbon in density fractions during post-agricultural succession over two lithology types, southwest China. J Environ Manage 201:199-206

Yang S, Jansen B, Absalah S, Hall R, Kalbitz K, Cammeraat ELH (2020) Lithology- and climate-controlled soil aggregate-size distribution and organic carbon stability in the Peruvian Andes. SOIL 6:1-15

Yeasmin S, Singh B, Johnston CT, Sparks DL (2017) Organic carbon characteristics in density fractions of soils with contrasting mineralogies. Geochim Cosmochim Acta 218:215-236

Yuan G, Soma M, Seyama H, Theng BKG, Lavkulich LM, Takamatsu T (1998) Assessing the surface composition of soil particles from some Podzolic soils by X-ray photoelectron spectroscopy. Geoderma 86(3):169-181

Zemek J, Olejnik K, Klapetek P (2008) Photoelectron spectroscopy from randomly corrugated surfaces. Surf Sci 602(7):1440-1446

Publisher's Note Springer Nature remains neutral with regard to jurisdictional claims in published maps and institutional affiliations. 